Review

\title{
Epigenetics and depression: return of the repressed
}

\author{
Victoria S. Dalton $^{\mathrm{a}, \mathrm{b}}$, Erik Kolshus ${ }^{\mathrm{a}, \mathrm{b}}$, Declan M. McLoughlin ${ }^{\mathrm{a}, \mathrm{b}, *}$ \\ a Trinity College Institute of Neuroscience, Trinity College Dublin, Dublin 2, Ireland \\ b Department of Psychiatry, Trinity College Dublin, St. Patrick's University Hospital, James's Street, Dublin 8, Ireland
}

\section{A R T I C L E I N F O}

\section{Article history:}

Received 16 July 2013

Received in revised form

15 October 2013

Accepted 16 October 2013

\section{Keywords:}

Epigenetics

Depression

microRNA

DNA methylation

Histone modification

\begin{abstract}
A B S T R A C T
Introduction: Epigenetics has recently emerged as a potential mechanism by which adverse environmental stimuli can result in persistent changes in gene expression. Epigenetic mechanisms function alongside the DNA sequence to modulate gene expression and ultimately influence protein production. The current review provides an introduction and overview of epigenetics with a particular focus on preclinical and clinical studies relevant to major depressive disorder (MDD).

Methods: PubMed and Web of Science databases were interrogated from January 1995 up to December 2012 using combinations of search terms, including "epigenetic", "microRNA" and "DNA methylation" cross referenced with "depression", "early life stress" and "antidepressant".

Results: There is an association between adverse environmental stimuli, such as early life stress, and epigenetic modification of gene expression. Epigenetic changes have been reported in humans with MDD and may serve as biomarkers to improve diagnosis. Antidepressant treatments appear to reverse or initiate compensatory epigenetic alterations that may be relevant to their mechanism of action. Limitations: As a narrative review, the current report was interpretive and qualitative in nature. Conclusion: Epigenetic modification of gene expression provides a mechanism for understanding the link between long-term effects of adverse life events and the changes in gene expression that are associated with depression. Although still a developing field, in the future, epigenetic modifications of gene expression may provide novel biomarkers to predict future susceptibility and/or onset of MDD, improve diagnosis, and aid in the development of epigenetics-based therapies for depression.
\end{abstract}

2013 Elsevier B.V. All rights reserved.

\section{Contents}

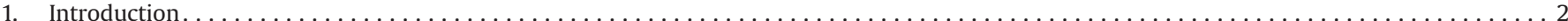

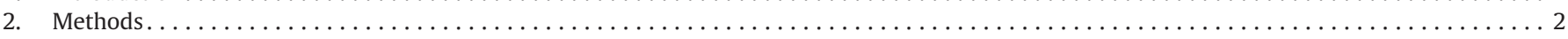

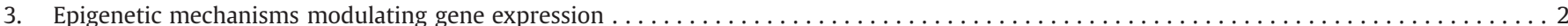

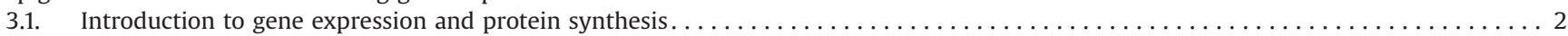

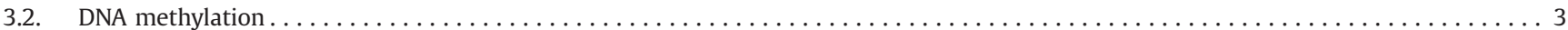

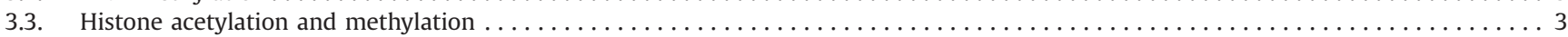

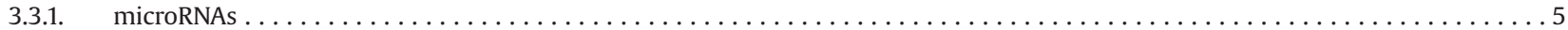

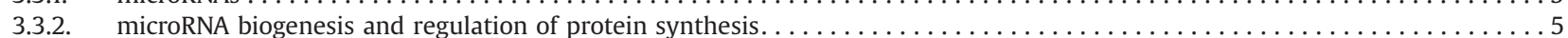

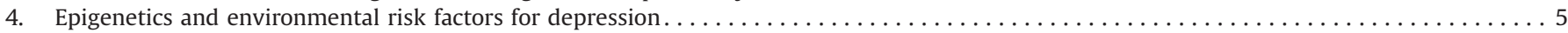

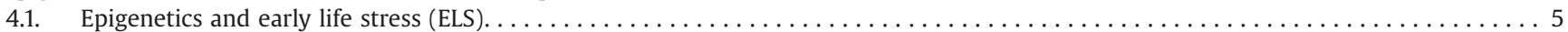

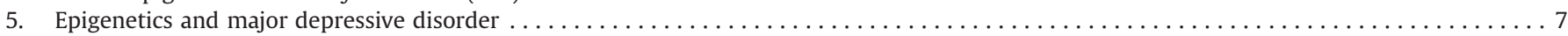

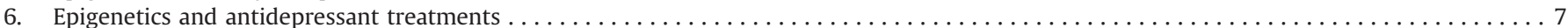

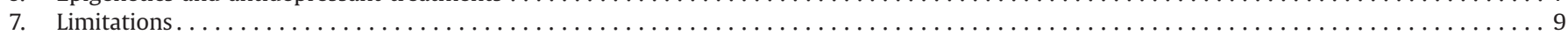

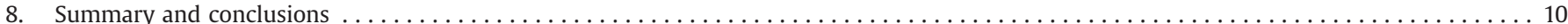

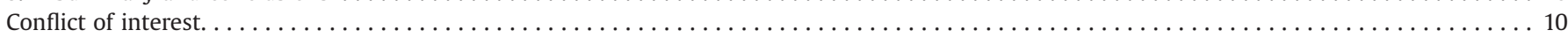

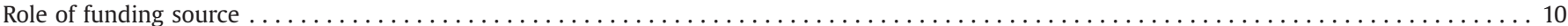

\footnotetext{
* Corresponding author at: Department of Psychiatry, Trinity College Dublin, St. Patrick's University Hospital, James's Street, Dublin 8, Ireland. Tel.: +353 12493385.

E-mail address: d.mcloughlin@tcd.ie (D.M. McLoughlin).
} 


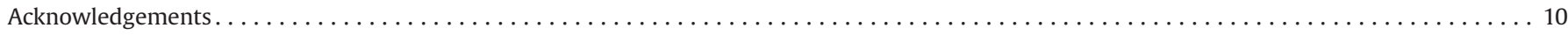

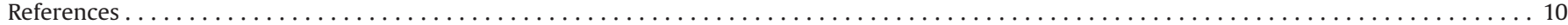

\section{Introduction}

The causes of major depressive disorder (MDD) remain unclear, posing a major gap in our knowledge and an obstacle to improving therapies. Although the heritability of MDD is between $31-42 \%$ (Edvardsen et al., 2009; Middeldorp et al., 2005), human genomewide association studies (GWAS) have failed to demonstrate reproducible gene loci that contribute to the disease (Wray et al., 2012). Furthermore, the high discordance rate of $50 \%$ between monozygotic twins suggests factors other than genetics contribute to disease genesis (Haque et al., 2009). Environmental stressors have been identified as risk factors for depression, although individual variability in the susceptibility to adverse environmental stimuli has been reported. Since MDD cannot be attributed to a single genetic mutation or exposure to one specific environmental cue, it has been proposed that MDD arises from genetic variation which is moderated by external influences (Kendler et al., 2002, 2006).

Epigenetics has recently emerged as a potential mechanism by which adverse environmental stimuli, such as stress encountered in early life, can result in stable, persistent alterations in gene expression (Onishchenko et al., 2008; Roth et al., 2009). The prefix "epi" means above or alongside and the term epigenetics refers to modulatory mechanisms that operate above or alongside the nucleotide bases that comprise a gene's deoxyribonucleic acid (DNA) sequence. Epigenetic mechanisms are thus responsible for alterations in the expression and function of a gene that are not encoded by the gene's DNA sequence itself. Epigenetic modifications in gene expression exert lasting changes without altering the genetic code (Schroeder et al., 2012). They are modifiable by environmental factors and are also potentially heritable (Franklin et al., 2010; Roth et al., 2009). This review aims to summarise current evidence of the role that epigenetic mechanisms, such as DNA methylation, histone acetylation and microRNA dysregulation, may play in depression, as well as what future directions this field may take.

\section{Methods}

Although the field of epigenetics is well developed in cancer and developmental biology, evidence for epigenetic modification of gene expression in mental disorders is only now emerging (Schroeder et al., 2012). Epigenetics offers an exciting new avenue for improving diagnosis and developing novel therapies and biomarkers for MDD. Given the novelty of the field and therefore the reasonably small number of relevant studies, we have conducted a narrative review of preclinical and clinical investigations. PubMed and Web of Science databases were interrogated from January 1995 up to December 2012 using combinations of search terms, including "epigenetic", "microRNA" and "DNA methylation" cross referenced with "depression", "early life stress" and "antidepressant". A total of 1576 potentially relevant articles were identified and 72 records removed when they did not meet the criteria of publication in a peer-reviewed journal and in the English language. Duplicate records were removed $(n=371)$. A total of 1133 titles were screened followed by 251 abstracts. After abstract screening, and also review of references from identified articles, a total of 77 full text papers were then reviewed for the current article. Our aims are to provide a scientific background to epigenetics and inform academic and clinical psychiatrists, and those in related disciplines, about epigenetics research in depression.

\section{Epigenetic mechanisms modulating gene expression}

\subsection{Introduction to gene expression and protein synthesis}

Genomic DNA constitutes the total genetic information of an organism and is made up of four different nucleotide bases guanine $(\mathrm{G})$, cytosine $(\mathrm{C})$, arginine $(\mathrm{A})$ and thymine $(\mathrm{T})$ - arranged to form a DNA double helix. The double helix consists of two chains of nucleotide bases organised in a specific order or "sequence" around a sugar-phosphate backbone. Bases that comprise the sequences are arranged in a complementary manner and attached to the backbone sugars to form base pairs such that $C$ is found opposite to $\mathrm{G}$ and $\mathrm{T}$ is found opposite to A (Fig. 1). Genomic DNA comprises regions of gene sequences, which ultimately give rise to proteins, along with other non-protein coding regions that are important in the control of gene expression or have an unknown function. Indeed, this non-coding DNA, previously considered to be "junk" DNA, is now attracting great interest. The Encyclopedia of DNA Elements (ENCODE) project, for example, has enabled researchers to assign biochemical functions for $80 \%$ of the human genome, particularly in non-protein coding regions that contain regulatory elements important in the control of gene expression (Encode Project Consortium, 2012).

Gene expression is the synthesis of a gene product (e.g. a protein) from the DNA sequence of a particular gene. Epigenetic factors can regulate gene expression at a number of levels (Fig. 1). During protein synthesis, first a gene is expressed within the cell nucleus as a ribonucleic acid (RNA) copy of its genomic DNA sequence, known as messenger RNA (mRNA) (Clancy and Brown, 2008). mRNA synthesis is activated by the binding of specific enzymes, known as mRNA transcription initiating factors, to a regulatory region of the DNA sequence called the promoter region (Fig. 1). It is at this transcriptional level that two modes of epigenetic regulation of gene expression may exert an effect in the form of chromatin remodelling and DNA methylation.

Genomic DNA is packaged as chromatin within the cell nucleus (Fig. 1). Chromatin can be remodelled and exists in open or closed functional states, which regulate enzymatic accessibility (Fig. 2B). When chromatin is in its open state, genomic DNA is accessible to the mRNA transcription initiating factors and facilitates gene expression. Chromatin in its closed state limits DNA accessibility for mRNA transcription initiating factors, thus suppressing gene expression. The mechanisms underlying chromatin remodelling are discussed in more detail below (Section 3.3).

DNA methylation is the second epigenetic factor that may have an effect on gene expression at the transcriptional level. It can suppress gene expression directly and indirectly by preventing the binding of enzymes important in RNA synthesis at the promoter region (Figs. 1 and 2D) (Hervouet et al., 2009; Szyf, 2006; Weber and Schubeler, 2007) and is discussed in more detail below (Section 3.2).

Provided that transcription factor binding is unhindered by the epigenetic modifications described above, the genomic DNA is then unwound and an enzyme known as RNA polymerase makes a 


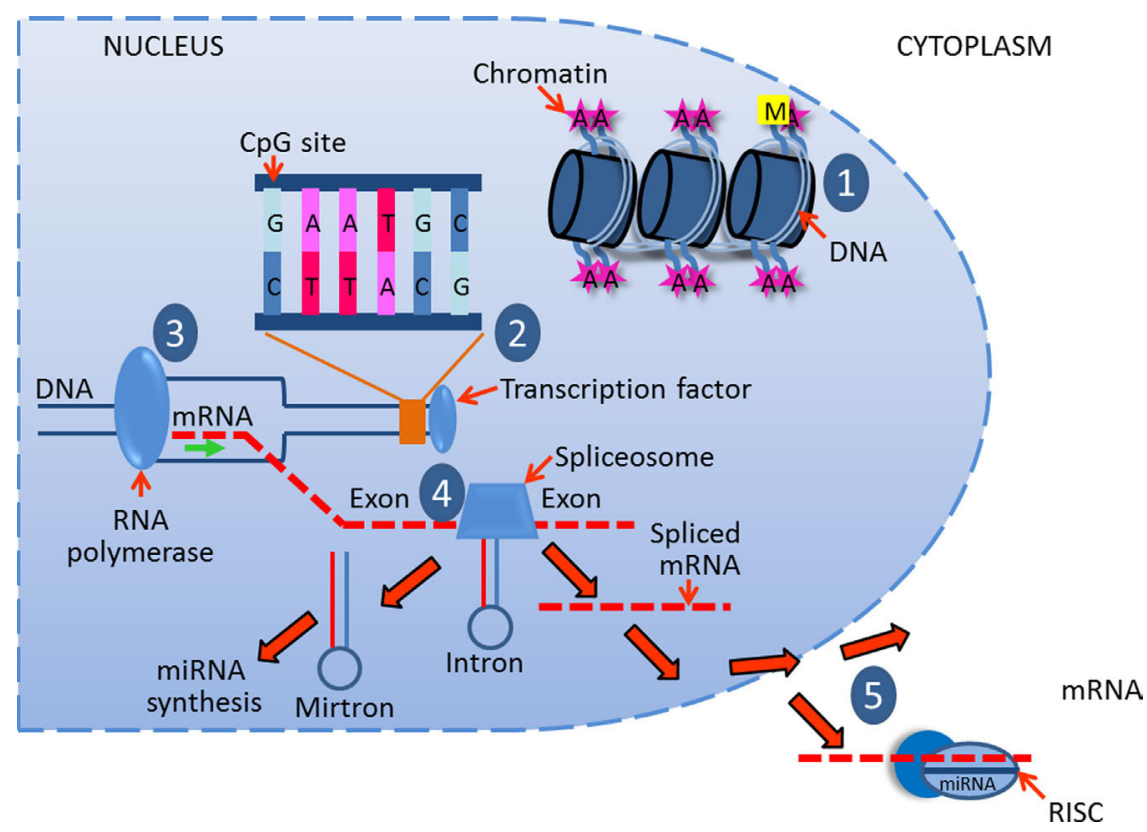

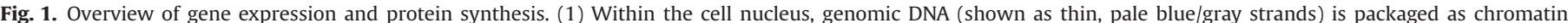

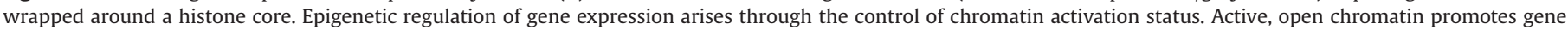

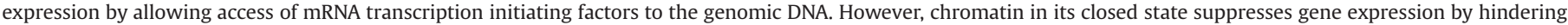

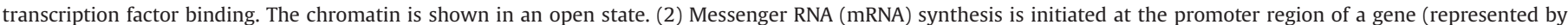

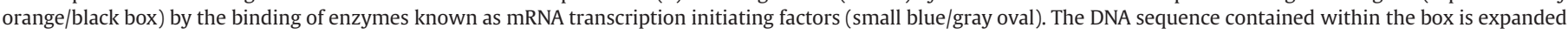

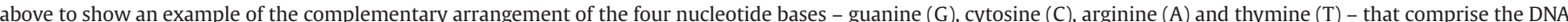

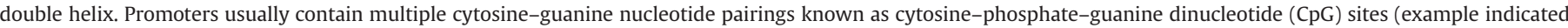

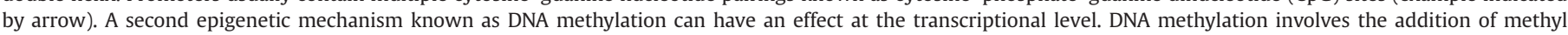

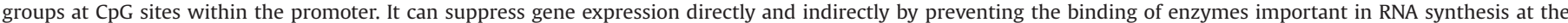

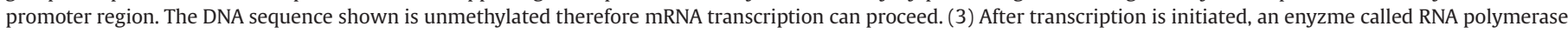

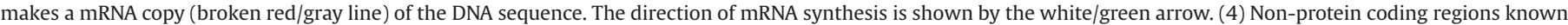

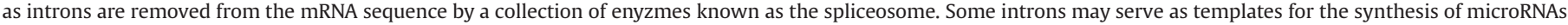

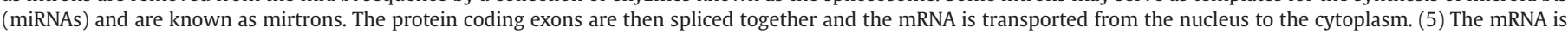

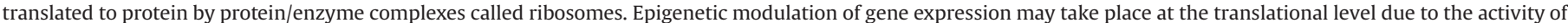

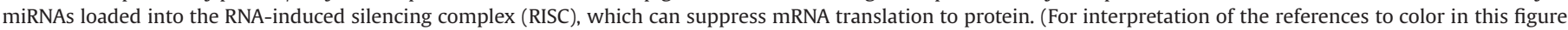
legend, the reader is referred to the web version of this article.)

mRNA copy of the DNA by creating a chain of nucleotides specified by the DNA gene sequence. Non-protein coding regions called introns are first removed from the synthesised mRNA by a process known as splicing. The processed mRNA is then transported outside the nucleus. It is at this point that microRNAs (miRNAs), another group of epigenetic modulators, may have an effect on gene expression. At this stage post-transcription, the mRNA sequence is usually translated into protein by complexes known as ribosomes. However, this process may be hindered by the presence of miRNAs thus leading to a decline in protein synthesis (discussed in more detail below in Section 3.3.2, see Figs. 1 and 3). Translation of mRNA to protein by ribosomes involves the linking of amino acids, the basic building blocks of proteins found within the cytoplasm, to form an amino acid chain. The amino acids that comprise the protein are determined by the mRNA sequence. Posttranslation, the amino acid chain then undergoes structural changes and folds in a specific manner to give rise to a protein.

\subsection{DNA methylation}

The most studied epigenetic modification to date is DNA methylation. Gene promoter regions usually contain multiple cytosine-guanine nucleotide pairings distributed repeatedly throughout, known as cytosine-phosphate-guanine dinucleotide (CpG) sites (Fig. 2D). DNA methylation generally entails the addition of a methyl group at $\mathrm{CpG}$ sites within the promoter region of a target gene by enzymes known as DNA methyltransferases (Fig. 2D) (Szyf, 2006; Weber and Schubeler, 2007). Methylation of CpG sites can suppress gene expression directly by preventing the binding of enzymes important in RNA synthesis at the promoter region (Hervouet et al., 2009; Szyf, 2006; Weber and Schubeler, 2007). CpG methylation can also hinder gene expression indirectly by recruiting enzymes and other proteins that promote gene-suppressive chromatin remodelling (discussed in detail below), ultimately leading to a decrease in protein production. Originally it was thought that the pattern of DNA methylation was laid down before birth and was irreversible in later life. Evidence has now emerged though that DNA methylation is responsive to, and alterable by, environmental signals (Weber and Schubeler, 2007).

\subsection{Histone acetylation and methylation}

To allow the storage of highly condensed genomic information within the cell nucleus, genomic DNA is organised in the form of chromatin. The basic unit of chromatin is called the nucleosome and it consists of approximately 147 nucleotide base pairs (bp) of negatively charged DNA sequence wrapped around a core of histone proteins (Fig. 2A) (Hayes and Hansen, 2001; Khorasanizadeh, 2004). Histones make up the major protein constituents of the nucleus. The nucleosome histone core contains two copies of four histone proteins: $\mathrm{H} 2 \mathrm{~A}, \mathrm{H} 2 \mathrm{~B}, \mathrm{H} 3$ and $\mathrm{H} 4$. Each core histone protein possesses an outward facing tail consisting of amino acids such as lysine (Fig. 2A). A fifth histone protein, $\mathrm{H1}$, acts as a linker between nucleosome units.

Modifications, such as the addition of acetyl or methyl groups at lysine residues on the histone tails (Fig. 2B and C), can change 
A

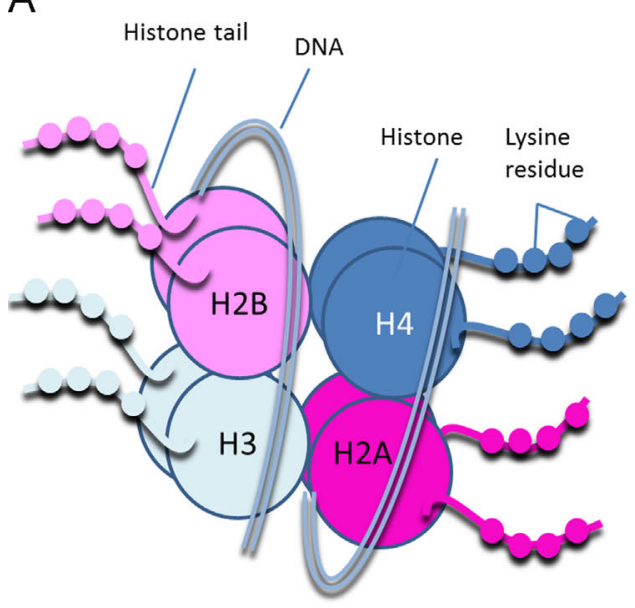

C

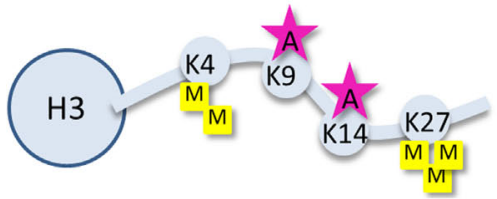

B

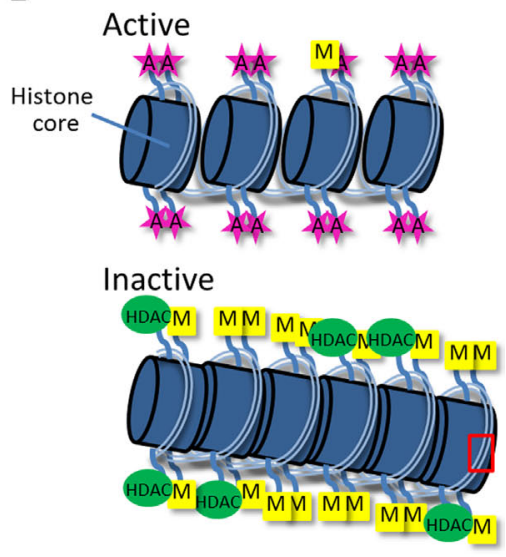

D

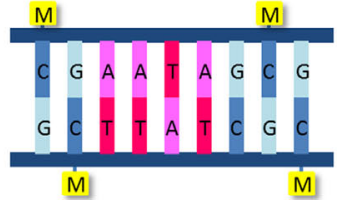

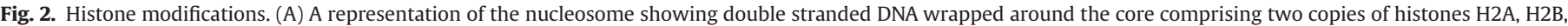

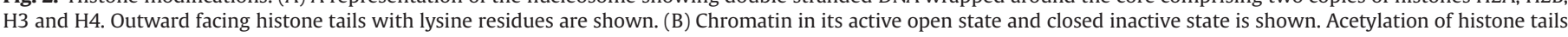

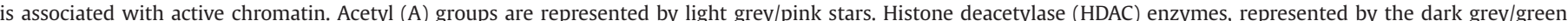

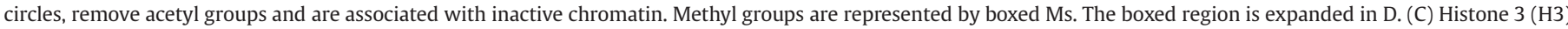

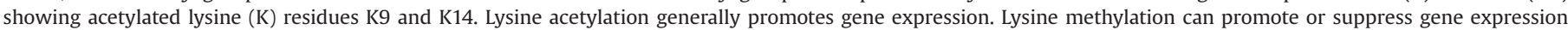

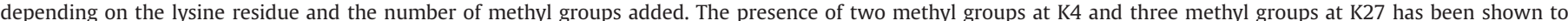

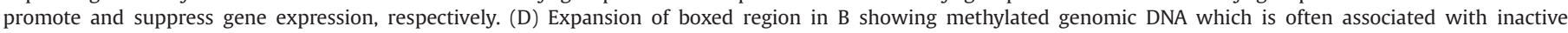

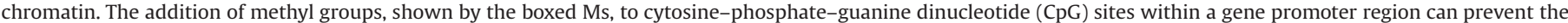

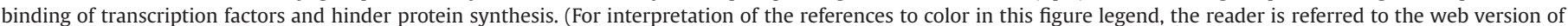
this article.)

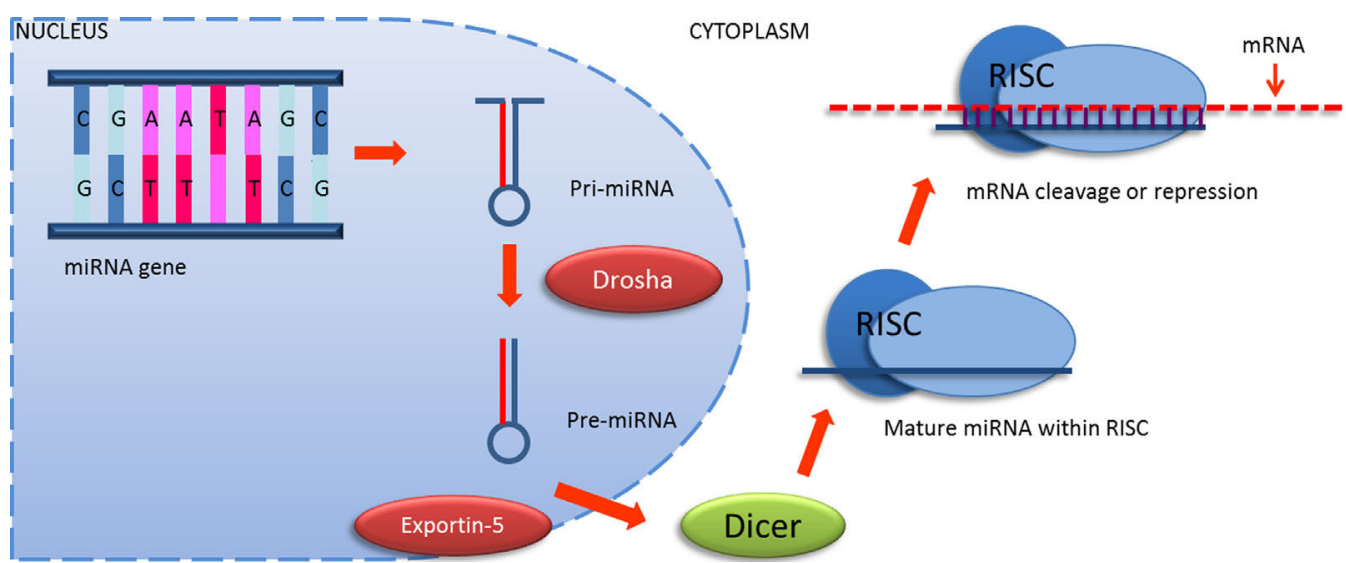

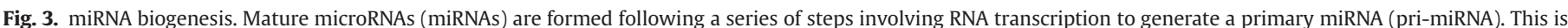

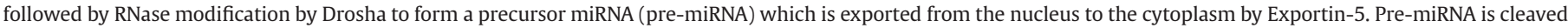

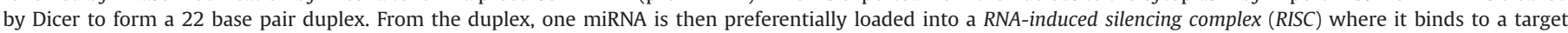
messenger RNA (mRNA) transcript, preventing translation.

the interaction between the genomic DNA and histone core, and are involved in control of gene expression (Berger, 2007; Hayes and Hansen, 2001). Chromatin enters its active state after addition of acetyl groups (hyperacetylation) to the histone tail by enzymes called histone acetyltransferases (HATs). This in turn promotes unfolding of the histone unit and decondensation of chromatin (Fig. 2B), allowing access of mRNA transcription initiating factors to the genomic DNA and promotes gene expression (Crosio et al., 2003; Eberharter and Becker, 2002; Grunstein, 1997; Hebbes et al., 1988; Korzus et al., 2004). On the other hand, removal of acetyl groups by enzymes known as histone deacetylases (HDACs) causes chromatin condensation (Fig. 2B) and decreases protein production (Grunstein, 1997; Pile et al., 2003). Alterations in the acetylation pattern of lysine residues comprising amino acid tails of histones 3 (Fig. 2C) and 4 have been implicated in depression (Iga et al., 2007; Levine et al., 2012; Onishchenko et al., 2008; Tsankova et al., 2006) and antidepressant treatment (Belzeaux et al., 2012; Dyrvig et al., 2012; Tsankova et al., 2006, 2004).

Alternatively to acetyl groups, methyl groups can be added to lysine residues on the histone tail (Fig. 2C). Chromatin activation status then depends on the particular lysine residue methylated as well as the number of methyl groups added to the residue (Fig. 2C) 
(Dillon et al., 2005; Morgunkova and Barlev, 2006). The addition of three methyl groups at lysine 27 to the amino acid tail of histone 3 is associated, for example, with silencing of gene transcription in depressed patients (Lopez et al., 2013) and in an animal model of depression (Onishchenko et al., 2008). On the other hand, the addition of two methyl groups to lysine 4 of histone 3 has been shown to promote gene expression in a depression model following antidepressant treatment (Tsankova et al., 2006).

Chromatin activation status and DNA methylation often work in concert to control gene expression. Chromatin status can usually be correlated with the DNA methylation pattern of a gene. Active chromatin is partnered with unmethylated DNA whereas inactive chromatin is associated with methylated DNA (Szyf, 2006; Tachibana et al., 2008).

\subsection{1. microRNAs}

In the past 10 years, miRNAs have emerged as another important group of epigenetic modulators of gene expression. They are endogenous non-protein coding RNA molecules of approximately 21-23 nucleotide bases that bind to complementary regions at target mRNAs and regulate mRNA translation to protein (Kolshus et al., 2013). Over 1500 mature miRNA sequences have been reported in the human to date (Kozomara and Griffiths-Jones, 2011) and it appears that over 50\% of mammalian mRNA species are potential targets for miRNAs (Friedman et al., 2009). A single mRNA may be regulated by multiple miRNAs and, conversely, some miRNAs have the potential to target hundreds of mRNAs. Typically, miRNAs suppress target gene expression; however, reciprocal relationships, whereby mRNA targets can control the level and function of miRNAs, are emerging (Pasquinelli, 2012). miRNAs are expressed during development and in adulthood, with the expression of some subsets being organ-specific (Sempere et al., 2004) and region-specific within organs such as the brain (Olsen et al., 2009). Functional studies indicate that miRNAs are involved in the control of many cellular processes including neurogenesis, synaptic plasticity, cell fate decision, and apoptosis (Bredy et al., 2011; Kloosterman and Plasterk, 2006; Luikart et al., 2012; Magill et al., 2010; Saba and Schratt, 2010). It follows therefore that dysregulation in their expression has been linked with human pathologies such as major depressive disorder, schizophrenia and cancer (Esteller, 2011; Im and Kenny, 2012).

\subsection{2. microRNA biogenesis and regulation of protein synthesis}

Biogenesis of miRNAs can occur through various different pathways (see Figs. 1 and 3) (Havens et al., 2012). In the canonical miRNA biogenesis pathway, primary miRNAs (pri-miRNA) are enzymatically transcribed from independent miRNA genes located within the genomic DNA (Fig. 3). Within the nucleus, a processing complex made up of multiple proteins then removes regions of the pri-miRNA to generate the double-stranded precursor miRNA (pre-miRNA), which is generally between 70 and 110 nucleotides in length. Pre-miRNAs can also be derived via alternative means. They can be directly transcribed, for example, from introns and are known as mirtrons (Fig. 1) (Chong et al., 2010; Krol et al., 2010). Following synthesis, pre-miRNAs are then exported from the nucleus to the cytoplasm (Yi et al., 2003), where the pre-miRNA is processed to form a $22 \mathrm{bp}$ molecule made up of two complementary RNA strands (Fig. 3) (Chendrimada et al., 2005). One strand from the duplex is then preferentially loaded into a protein complex called the RNA-induced silencing complex (RISC) (Kawamata and Tomari, 2010). Once loaded into the RISC, the miRNA guides the complex to the target mRNA transcripts (Figs. 1 and 3). Depending on the number of sequence mismatches between the miRNA and its mRNA target, miRNA induced regulation of the mRNA then occurs due to enzymatic degradation of the target or prevention of mRNA translational to protein due to steric hindrance of protein synthesis machinery (Carthew and Sontheimer, 2009; Krol et al., 2010; Wu et al., 2006).

\section{Epigenetics and environmental risk factors for depression}

Epigenetics provides a potential mechanism by which adverse stimuli can result in lasting changes in gene expression. Preclinical and clinical studies have recently focused on the epigenetic effects of various environmental stressors that have been identified as risk factors for poor mental health outcome. Epigenetic modifications of gene expression have been reported in rodent models after acute stress (Fuchikami et al., 2009), chronic stress (Sterrenburg et al., 2011; Tsankova et al., 2006; Uchida et al., 2011; Wilkinson et al., 2009), fear conditioning (Bredy et al., 2007; Mizuno et al., 2012) and in a rat model of post-traumatic stress disorder (Roth et al., 2011). In addition to these studies, the epigenetic changes elicited by exposure to early life stress (ELS) have been a major focus of research into the epigenetic mechanisms involved in the pathogenesis of MDD in rodent models (Table 1) and humans. Evidence suggests that adverse external stimuli encountered in early life can affect adult behaviour and predispose individuals to lifelong health problems, including increased risk of mental illnesses such as depression (Heim and Binder, 2012; Markham and Koenig, 2011; Talge et al., 2007). Epigenetic mechanisms such as DNA methylation, histone modifications and dysregulation of microRNA expression represent plausible means by which ELS may cause lifelong changes in gene expression.

\subsection{Epigenetics and early life stress (ELS)}

In animal models of depression, evidence exists for an association between ELS and epigenetic modulation of a range of genes previously implicated in depression. Alterations in DNA methylation and histone modifications at promoters of genes, such as brain derived neurotrophic factor (Bdnf), as well as changes in miRNA expression patterns, have been reported in the rodent brain after exposure to prenatal and/or perinatal stress (see Table 1 for a summary). Exposure to methylmercury from gestational day 7 to postnatal day 7 , for example, has been shown to result in depressive-like behaviour in mice (Onishchenko et al., 2008). Methylmercury-exposed pups show a decrease in hippocampal $B d n f$ mRNA that is accompanied by increases in gene-suppressing methylation of DNA and histone 3 at lysine 27, and a decrease in expression-promoting acetylation of histone 3 at a Bdnf promoter region. Postnatal stressors such as maternal separation and/or exposure to low levels of maternal care or attention have also been linked with changes in DNA methylation and chromatin activation status of various genes expressed in the rodent brain (Table 1). Maltreatment of rat pups by stressed caretakers in early development (between postnatal days 1 and 7) resulted in decreased Bdnf mRNA expression in the prefrontal cortex that was accompanied by an increase in expression-suppressing DNA methylation at Bdnf promoter regions in adulthood, an effect that could be reversed by the application of the DNA methyltransferase inhibitor, zebularine (Roth et al., 2009).

Altered DNA methylation patterns of genes implicated in depression such as BDNF (Toledo-Rodriguez et al., 2010), the glucocorticoid receptor (Mulligan et al., 2012; Oberlander et al., 2008; Radtke et al., 2011) and serotonin transporter (Devlin et al., 2010), have been reported in children following exposure of mothers to prenatal stressors such as smoking, maternal depression, partner violence and war. Adversities experienced in early childhood have also been 
Table 1

Studies of epigenetic modification of gene expression following exposure to early life stress in rodent models.

\begin{tabular}{|c|c|c|c|c|c|}
\hline Reference & $\begin{array}{l}\text { Species/ } \\
\text { strain }\end{array}$ & Stressor & $\begin{array}{l}\text { Region/ } \\
\text { age } \\
\text { assessed }\end{array}$ & Epigenetic modification & Molecular and behavioural changes \\
\hline $\begin{array}{l}\text { Bai et al. } \\
\text { (2012) }\end{array}$ & SD rats & MS from PD 1-13 & $\begin{array}{l}\mathrm{HC} / \\
>\text { PD } 91\end{array}$ & $\uparrow \operatorname{miR} 16$ & $\begin{array}{l}\downarrow \text { Total BDNF mRNA inversely correlated with miR16 } \\
\text { expression } \\
\text { Depression-like behaviour }\end{array}$ \\
\hline $\begin{array}{l}\text { Chen et al. } \\
\text { (2012) }\end{array}$ & SD rats & MS from PD 2-13 & $\begin{array}{l}\text { PVN and } \\
\text { AMY/PD } \\
60\end{array}$ & $\downarrow$ DNA methylation of CRH in PVN & $\begin{array}{l}\uparrow \text { Heteronuclear RNA (mRNA precursor) for CRH } \\
\text { following acute stress } \\
\uparrow \text { Plasma CORT in response to stress }\end{array}$ \\
\hline $\begin{array}{l}\text { Jiao et al. (in } \\
\text { press) }\end{array}$ & $\begin{array}{l}\mathrm{BALB} / \mathrm{CJ} \\
\& \mathrm{C} 57 \mathrm{BL} / \\
6 \mathrm{~J} \text { mice }\end{array}$ & $\begin{array}{l}\text { Strain-specific effects } \\
\text { of gestational } \\
\text { environment and } \\
\text { maternal care }\end{array}$ & $\begin{array}{l}\mathrm{HC} / \mathrm{PD} \\
84-112\end{array}$ & $\begin{array}{l}\uparrow D N A \text { methylation for CRP in BALB/cJ -gestated } \\
\text { mice, no effect of maternal care on CRP DNA } \\
\text { methylation }\end{array}$ & $\begin{array}{l}\uparrow C R P \text { mRNA in C57BL/6J gestated mice } \\
\text { No effect of maternal care on CRP expression } \\
\text { C57BL/6J gestated mice showed increased depression- } \\
\text { like behaviour }\end{array}$ \\
\hline $\begin{array}{l}\text { Levine et al. } \\
\text { (2012) }\end{array}$ & $\begin{array}{l}\mathrm{BALB} / \mathrm{CJ} \\
\& \mathrm{C} 57 \mathrm{BL} / \\
6 \mathrm{~J} \text { mice }\end{array}$ & $\begin{array}{l}\text { Strain-specific effects } \\
\text { of MS from PD 2-15 }\end{array}$ & $\begin{array}{l}\text { Cortex/ } \\
\text { PD 21, } \\
28 \text { and } \\
60\end{array}$ & $\uparrow \mathrm{H} 4 \mathrm{~K} 12$ acetylation in Balb/cJ mice after MS & $\begin{array}{l}\downarrow \text { HDAC mRNA in Balb/cJ mice after MS } \\
\text { Depression-like behaviour in Balb/cJ mice after MS }\end{array}$ \\
\hline $\begin{array}{l}\text { Matrisciano } \\
\text { et al. (2013) }\end{array}$ & $\begin{array}{l}\text { ND4 } \\
\text { mice }\end{array}$ & $\begin{array}{l}\text { Prenatal restraint } \\
\text { stress }\end{array}$ & FC/PD 60 & $\uparrow$ DNA methylation of GAD67 and reelin & $\begin{array}{l}\uparrow \text { GAD67 and reelin protein, } \uparrow \text { mRNA expression and } \\
\text { protein levels of DNA methyltransferase enzymes } \\
\text { Hyperactivity and deficits in social interaction, PPI and } \\
\text { fear conditioning }\end{array}$ \\
\hline $\begin{array}{l}\text { Mueller and } \\
\text { Bale (2008) }\end{array}$ & $\begin{array}{l}\text { C57BL/ } \\
6: 129 \\
\text { mice }\end{array}$ & $\begin{array}{l}\text { Chronic variable PS } \\
\text { from GD 1-7 }\end{array}$ & $\begin{array}{l}\text { HYP, } \\
\text { AMY, } \\
\text { HC/PD } \\
120\end{array}$ & $\begin{array}{l}\text { DNA methylation of CRH } \downarrow \text { in HYP and AMY, and of } \\
\text { GR } \uparrow \text { in HYP }\end{array}$ & $\begin{array}{l}\uparrow \mathrm{CRH} \text { mRNA in HYP and AMY, } \downarrow \text { GR in HC } \\
\text { Depression-like behaviour }\end{array}$ \\
\hline $\begin{array}{l}\text { Murgatroyd } \\
\text { et al. } \\
\text { (2009) }\end{array}$ & $\begin{array}{l}\text { C57BL/ } \\
6 \mathrm{~N} \text { mice }\end{array}$ & MS from PD 1-10 & $\begin{array}{l}\text { PVN /PD } \\
42,84 \\
\text { and } \\
1 \text { year }\end{array}$ & $\downarrow$ DNA methylation of arginine vasopressin & $\begin{array}{l}\uparrow \text { Arginine vasopressin mRNA } \\
\uparrow \text { Serum CORT response to stress and memory deficits }\end{array}$ \\
\hline $\begin{array}{l}\text { Mychasiuk } \\
\text { et al. (2011) }\end{array}$ & LE rats & $\begin{array}{l}\text { Mild or high PS from } \\
\text { GD12-16 }\end{array}$ & $\begin{array}{l}\mathrm{FC}, \mathrm{HCl} \\
\mathrm{PD} 21\end{array}$ & $\begin{array}{l}\text { Global DNA methylation } \uparrow \text { with mild PS and } \downarrow \text { with } \\
\text { high PS }\end{array}$ & $\begin{array}{l}\text { Mild PS }=\downarrow \text { locomotion } \\
\text { High PS }=\uparrow \text { locomotion }\end{array}$ \\
\hline $\begin{array}{l}\text { Novikova } \\
\text { et al. } \\
\text { (2008) }\end{array}$ & $\begin{array}{l}\text { CD1 } \\
\text { mice }\end{array}$ & $\begin{array}{l}\text { Maternal cocaine }(20 \\
\mathrm{mg} / \mathrm{kg}) \text { from GD8-19 }\end{array}$ & $\begin{array}{l}\mathrm{HC} / \mathrm{PD} \\
3 \text { and } 30\end{array}$ & Global DNA methylation $-\downarrow$ PD3 and $\uparrow P D ~ 30$ & $\begin{array}{l}\text { Expression of selected genes was linked to DNA } \\
\text { methylation }\end{array}$ \\
\hline $\begin{array}{l}\text { Onishchenko } \\
\text { et al. } \\
\text { (2008) }\end{array}$ & $\begin{array}{l}\text { C57BL/ } \\
6 / \mathrm{Bk} 1 \\
\text { mice }\end{array}$ & $\begin{array}{l}\text { Dams exposed to } \\
\text { methylmercury from } \\
\text { GD7-PD7 }\end{array}$ & $\begin{array}{l}\mathrm{HC} / \mathrm{PD} \\
84 \text { and } \\
14 \\
\text { months }\end{array}$ & $\begin{array}{l}\uparrow \mathrm{H} 3 \mathrm{~K} 27 \text { tri-methylation, } \downarrow \mathrm{H} 3 \mathrm{~K} 9 \mathrm{~K} 14 \text { acetylation } \\
\text { and } \uparrow \mathrm{DNA} \text { methylation at BDNF promoter }\end{array}$ & $\begin{array}{l}\downarrow \text { Total BDNF mRNA } \\
\text { Depression-like behaviour }\end{array}$ \\
\hline $\begin{array}{l}\text { Roth et al. } \\
\text { (2009) }\end{array}$ & LE rats & $\begin{array}{l}\text { Abusive caretaker } \\
\text { exposure from PD 1-7 }\end{array}$ & $\begin{array}{l}\text { FC/PD 8, } \\
30 \text { and } \\
90\end{array}$ & $\uparrow D N A$ methylation at BDNF promoters & $\downarrow$ Total BDNF mRNA \\
\hline $\begin{array}{l}\text { Uchida et al. } \\
\text { (2010) }\end{array}$ & SD rats & MS from PD 2-14 & $\begin{array}{l}\text { FC/PD } 14 \\
\text { and } 58- \\
60\end{array}$ & $\begin{array}{l}\text { PD14: } \uparrow \text { in precursor miR-132, }-124-1,-9-1,-9-3 \text {, } \\
-212 \text {, and }-29 \text { a and } \uparrow \text { in mature miR132, }-124 \text {, miR9 } \\
\text { and }-29 a \text {; PD 58-60: } \uparrow \text { precursor miR-124, }-212 \text { and } \\
-132\end{array}$ & $\begin{array}{l}\uparrow \text { mRNA for GluR2, NMDA receptor } 1 \text { subunit, CRH, } \\
\text { CAM kinase II, cell adhesion molecule L1, adenylate } \\
\text { cyclase } 5,5 \text { HT1aR and voltage-gated potassium } \\
\text { channel subunit Kv3.1, } \downarrow \text { mRNA for neuron navigator } 1 \\
\text { MS rats showed a greater HPA axis response to stress } \\
\text { than controls. }\end{array}$ \\
\hline $\begin{array}{l}\text { Weaver et al. } \\
\text { (2004) }\end{array}$ & LE rats & $\begin{array}{l}\text { Effects of high and low } \\
\text { levels of maternal care } \\
\text { PD } 1-7\end{array}$ & $\begin{array}{l}\mathrm{HC} / \mathrm{PD} \\
90\end{array}$ & $\begin{array}{l}\uparrow D N A \text { methylation and } \downarrow \text { H3K9 acetylation of GR } \\
\text { after low level maternal care }\end{array}$ & $\begin{array}{l}\downarrow G R \text { protein } \\
\uparrow \text { Plasma CORT in response to stress }\end{array}$ \\
\hline
\end{tabular}

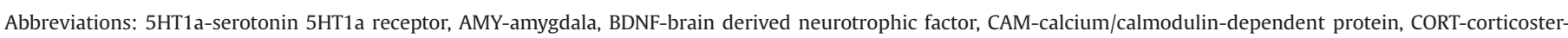

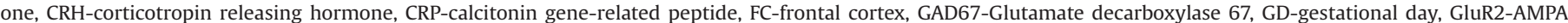

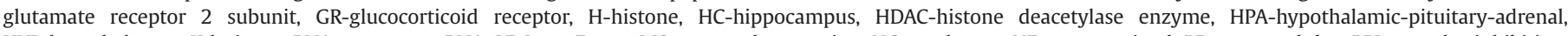

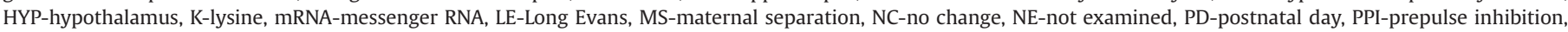
PS-prenatal stress, PVN-paraventricular nucleus of hypothalamus, SD-Sprague Dawley.

linked to epigenetic modulation of gene expression. Variations in DNA methylation status of the glucocorticoid receptor and ribosomal RNA promoter have been reported in the postmortem brains of suicide victims with a history of childhood abuse (McGowan et al., 2009, 2008). Additionally, early life poverty was associated with DNA methylation in an analysis of $>14,000$ genes in peripheral blood mononuclear cells in a community-based cohort stratified for early-life socioeconomic status (Lam et al., 2012).

Taken together, these studies indicate that exposure to a range of pre- and post-natal stressors are associated with epigenetic modifications in depression-related genes in both rodent models of ELS (Table 1) and in humans. Epigenetics may thus be one of the underlying mechanisms by which ELS exerts long-term effects on gene expression in individuals and their offspring. Epidemiological studies have shown that the offspring of individuals exposed to ELS may display behavioural/developmental disturbances similar to their parent even if they themselves have not experienced the trauma. Furthermore, these disturbances can be passed on to the subsequent generations (Brand et al., 2010; Harper, 2005; Kim et al., 2009). Persistent epigenetic modification of gene expression induced by an environmental stimulus, e.g. ELS, has been suggested as one of the mechanisms underlying transgenerational phenotypic transmission (Harper, 2005). Preclinical research in rodent models supports this hypothesis (Franklin et al., 2010; Morgan and Bale, 2011; Roth et al., 2009). However, a considerable amount of further study is required to fully understand the range of genes epigenetically regulated by exposure to early life stress and the implications for future generations. 


\section{Epigenetics and major depressive disorder}

Altered DNA methylation and chromatin activation status have been reported in humans with depression (see Table 2). Researchers have examined genome-wide DNA methylation patterns as well as epigenetic modification of individual depression-related genes such as the $\gamma$-aminobutyric acid (GABA) receptor subunits, synapsins and serotonin transporter as well as mRNA expression of enzymes involved in epigenetic modifications in patients with MDD (Table 2). Given the alterations in BDNF and its receptor Trk B observed in individuals with MDD (Dwivedi et al., 2003; Kim et al., 2007; Lee and Kim, 2010; Thompson Ray et al., 2011), particular attention has focused on epigenetic modification of the BDNF pathway in depression (Boulle et al., 2012). Alterations in DNA methylation of promoter regions of $B D N F$ have been reported in the blood of patients with MDD (Fuchikami et al., 2011). Keller et al. (2010) observed an increase in DNA methylation at a BDNF promoter that was associated with decreased BDNF mRNA levels in Wernicke's area in brains of suicide victims, some of whom had a diagnosis of MDD (Keller et al., 2010). In the same cohort however, mRNA expression and DNA methylation of the BDNF receptor, $\operatorname{Trk} B$, and its truncated form, Trk B-T1, in Wernicke's area did not correlate with suicidal behavior (Keller et al., 2011). On the other hand, decreased Trk B-T1 mRNA in the frontal cortex was associated with increased methylation of CpG sites (Ernst et al., 2009b) and histone 3 at lysine 27 (Ernst et al., 2009a) in the promoter region of Trk B-T1 in suicide completers, some of whom had MDD.

The few studies conducted to date in human subjects also provide evidence for alterations in miRNA directed translational regulation of coded proteins in major depression (Table 2). Recently, for example, Smalheiser et al. (2012) found that global miRNA expression was decreased and reorganised in a depressed suicide cohort compared to controls. The expression levels of 365 miRNAs were compared in the prefrontal cortex (Brodmann area 9) in 18 antidepressant-free depressed suicide subjects with
17 controls. The authors observed a global decrease in miRNA expression in the suicide group and identified 21 miRNAs that showed a statistically significant decrease of $30 \%$ or more. Approximately half of the downregulated miRNAs shared putative mRNA targets, including some that have been implicated in depression such as vascular endothelial growth factor and B-cellCLL/lymphoma 2, and in the epigenetic control of gene expression including DNA methyltransferase 3b (Smalheiser et al., 2012). miRNAs exert their influence by binding to target mRNAs and ultimately suppressing protein synthesis according to sequence complementarity. Polymorphisms, which are naturally occurring variations in nucleotide sequences, have the potential to affect miRNA binding potential, and ultimately, miRNA-directed regulation of protein synthesis. In addition to changes in miRNA levels, polymorphisms in miRNAs and their precursors, their target mRNAs and in genes that regulate miRNA biogenesis have also been reported in MDD (Table 2).

Collectively, these studies suggest that alterations in DNA methylation, histone modifications and miRNA expression play an important role in dysregulation of gene expression in MDD. Clearly more research in epigenetic alteration of gene expression in individuals with depression is required, particularly into the role of chromatin activation status and miRNA changes in MDD given the paucity of literature on these topics. With further understanding, epigenetic modifications may serve as potential biomarkers to improve diagnosis and better understand the pathophysiology of MDD.

\section{Epigenetics and antidepressant treatments}

As well as its role in the pathogenesis of depression, research in animal models and humans suggests that epigenetic modulation of gene expression is also involved in the mechanisms of action of antidepressants (see Tables 3 and 4). Alterations in DNA

Table 2

Clinical studies of epigenetic modifications in mood disorders.

\begin{tabular}{|c|c|c|c|}
\hline Reference & Tissue & Diagnosis & Epigenetic modification, molecular changes and other outcomes \\
\hline Cruceanu et al. (2013) & $\begin{array}{l}\text { Prefrontal cortex } \\
\text { (BA 10) }\end{array}$ & MDD or BP & $\begin{array}{l}\uparrow \mathrm{H} 3 \mathrm{~K} 4 \text { methylation at SYN1 promoter in MDD } \\
\uparrow \mathrm{mRNA} \text { for SYN1a in BP and MDD } \\
\uparrow \mathrm{mRNA} \text { for SYN1b in MDD only } \\
\uparrow \mathrm{H} 3 \mathrm{~K} 4 \text { methylation at SYN2 promoter in BP } \\
\uparrow \mathrm{mRNA} \text { for SYN2a in BP and } \\
\uparrow \mathrm{mRNA} \text { for SYN2b in MDD }\end{array}$ \\
\hline $\begin{array}{l}\text { Ernst et al. (2009a), Ernst } \\
\text { et al. (2009b) }\end{array}$ & Frontal cortex & $\begin{array}{l}\text { Suicide completers, some of } \\
\text { whom had MDD }\end{array}$ & $\begin{array}{l}\uparrow \mathrm{DNA} \text { and H3K27 methylation of Trk B-T1 } \\
\downarrow \text { Trk B-T1 mRNA }\end{array}$ \\
\hline Fuchikami et al. (2011) & Blood & MDD & Altered BDNF DNA methylation pattern in MDD \\
\hline He et al. (2012) & Blood & MDD & $\begin{array}{l}\text { SNPs in microRNA processing genes in DGCR8 and AGO1 } \\
\text { DGCR8 SNP associated with } \uparrow \text { suicide risk and improved antidepressant response and } \\
\text { AGO1 SNP associated with } \downarrow \text { suicide risk }\end{array}$ \\
\hline Iga et al. (2007) & Blood & MDD & $\uparrow$ HDAC 5 mRNA \\
\hline $\begin{array}{l}\text { Keller et al. (2011), Keller } \\
\text { et al. (2010) }\end{array}$ & Wernicke's area & $\begin{array}{l}\text { Suicide completers, some of } \\
\text { whom had MDD }\end{array}$ & $\begin{array}{l}\uparrow D N A \text { methylation and } \downarrow \text { mRNA for BDNF but no correlation between Trk } B \text { and Trk B-T1 } \\
\text { DNA methylation and suicide }\end{array}$ \\
\hline Philibert et al. (2008) & $\begin{array}{l}\text { Lymphoblast cell } \\
\text { lines }\end{array}$ & MDD & $\begin{array}{l}\text { Females showed higher levels of DNA methylation of SERT compared to males } \\
\text { Trend for association between } \uparrow \text { SERT DNA methylation and MDD }\end{array}$ \\
\hline Poulter et al. (2008) & Frontal cortex & Suicide completers with MDD & $\uparrow D N A$ methylation of $G_{A B A_{A}}$ receptor subunit $\alpha 1$ \\
\hline Rahman et al. (2010) & $\begin{array}{l}\text { Buccal epithelial } \\
\text { cells }\end{array}$ & $\mathrm{MDD}$ or $\mathrm{BP}$ & $\begin{array}{l}\text { Association between a polymorphism in } \mathrm{P} 2 \mathrm{X} 7 \text { purinergic receptor gene and target site for } \\
\text { miR-625 and }-1302\end{array}$ \\
\hline Saus et al. (2010) & Blood & MDD & $\begin{array}{l}\text { Association between a polymorphism in the circadian clock modulator pre-miR-182 and } \\
\text { late insomnia }\end{array}$ \\
\hline Smalheiser et al. (2012) & $\begin{array}{l}\text { Prefrontal cortex } \\
\text { (BA 9) }\end{array}$ & Suicide completers with MDD & $\begin{array}{l}\text { Global } \downarrow \text { and reorganisation in miRNA expression in MDD } \\
\downarrow 21 \text { miRNAs }\end{array}$ \\
\hline Uddin et al. (2011) & Blood & MDD & Altered DNA methylation pattern in MDD \\
\hline Xu et al. (2010) & Blood & MDD & $\begin{array}{l}\text { Polymorphism in pre-miR30e associated with MDD and difficulties with the speed of } \\
\text { perception and processing of auditory stimuli }\end{array}$ \\
\hline
\end{tabular}

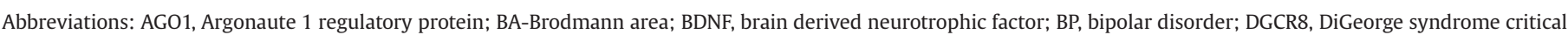

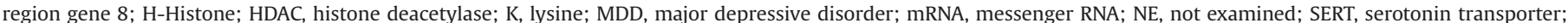
SNPs, single nucleotide polymorphism; SYN, synapsin; Trk B-T1, truncated form of tyrosine kinase B receptor. 
methylation and chromatin activation status have been reported after antidepressant administration in preclinical and clinical investigations. In addition, antidepressants also appear to act by modifying miRNA expression, as evidenced by in vitro studies and research in animal models and humans.

Electroconvulsive therapy (ECT) is the most acutely effective treatment available for severe depression (Eranti et al., 2007; UK Ect Review Group, 2003). The precise mechanisms of action of ECT remain unknown but evidence in animal models suggests that treatment with ECS (electroconvulsive stimulation), the animal model equivalent of ECT, results in epigenetic modification of gene expression (Table 3). Tsankova et al. (2004), for example, examined histone modifications of Bdnf at $30 \mathrm{~min}$, two hours and $24 \mathrm{~h}$ after acute and chronic ECS in the rat brain hippocampus. Their results indicated that histone modifications controlling the expression of Bdnf after ECS administration are dependent on treatment duration, post-treatment time and gene promoter region. ECS also results in histone modifications and accompanying alterations in mRNA for CREB and c-Fos (Dyrvig et al., 2012; Tsankova et al., 2004) as well as an increase in DNA methylation at the Arc promoter (Dyrvig et al., 2012). Taken together, these findings imply that epigenetic modulation of gene expression is important

Table 3

Antidepressant treatment associated epigenetic modifications in in vitro and preclinical studies.

\begin{tabular}{|c|c|c|c|c|}
\hline Reference & Species & Tissue & Treatment & Treatment associated epigenetic modification, molecular changes and other outcomes \\
\hline Angelucci et al. (2011) & Human & $\begin{array}{l}\text { Cell } \\
\text { line }\end{array}$ & Paroxetine & $\begin{array}{l}\text { Rapid } \uparrow \text { in } B D N F \text { mRNA expression and protein synthesis followed by } \uparrow \text { in miR-30a-5p, a BDNF inhibitor, } \\
\text { at six and } 12 \mathrm{~h} \text { after treatment }\end{array}$ \\
\hline \multirow{3}{*}{$\begin{array}{l}\text { Baudry et al. (2010), } \\
\text { Launay et al. (2011) }\end{array}$} & \multirow[t]{3}{*}{ Mouse } & RN & Fluoxetine applied at & $\downarrow$ miR-16 and serotonin transporter in $\mathrm{RN}$ \\
\hline & & LC & RN for 3 days & $\downarrow \mathrm{miR}-16$ and $\uparrow$ serotonin transporter in $\mathrm{LC}$ and $\mathrm{HC}$ \\
\hline & & $\mathrm{HC}$ & & Anti-miR-16 applied at $\mathrm{HC}$ results in anti-depressant behaviour \\
\hline Dyrvig et al. (2012) & SD rat & $\mathrm{HC}$ & ECS, 1 day & $\uparrow \mathrm{H} 4$ acetylation at $C$-fos promoter $1 \mathrm{hr}$ post-ECS, $\uparrow$ DNA methylation of $\operatorname{Arc} 24 \mathrm{hr}$ post-ECS \\
\hline \multirow[t]{2}{*}{ Melas et al. (2012) } & \multirow[t]{2}{*}{ FSL rat } & \multirow[t]{2}{*}{ PFC } & Escitalopram, & Pre-treatment: $\uparrow$ DNA methylation, $\downarrow$ mRNA and protein of P11 membrane trafficking protein \\
\hline & & & 3 weeks & $\begin{array}{l}\text { Post-treatment: P11 DNA methylation returned to control levels, } \uparrow \text { P11 mRNA, } \downarrow \text { mRNA for DNA } \\
\text { methyltransferase enzymes, Dnmt } 1 \text { and Dnmt } 3 a\end{array}$ \\
\hline $\begin{array}{l}\text { Onishchenko et al. } \\
\text { (2008) }\end{array}$ & Mouse & $\mathrm{HC}$ & $\begin{array}{l}\text { Fluoxetine, } 21 \text { days } \\
\text { from PND } 63\end{array}$ & $\begin{array}{l}\uparrow \mathrm{H} 3 \text { acetylation at } B d n f \text { promoter and } \uparrow B d n f \text { mRNA compensating for epigenetic effects of perinatal } \\
\text { methylmercury exposure (Table } 1 \text { ) }\end{array}$ \\
\hline \multirow[t]{2}{*}{ Oved et al. (2012) } & \multirow[t]{2}{*}{ Human } & \multirow[t]{2}{*}{$\begin{array}{l}\text { Cell } \\
\text { line }\end{array}$} & \multirow[t]{2}{*}{ Paroxetine, 3 days } & $\begin{array}{l}\text { Paroxetine sensitive cells had higher basal expression levels of miR-151-3p, associated with } \downarrow \text { mRNA for } \\
\text { miR-151-3p effector, CHL1, a neural cell adhesion molecule }\end{array}$ \\
\hline & & & & $\begin{array}{l}\text { Basal levels of miR-212, mir- } 132 \text {, miR- } 30 b^{*} \text {, let- } 7 \mathrm{~b} \text { and let-7c also differed significantly by more than } \\
1.5 \text { fold between the high and low sensitivity cell groups }\end{array}$ \\
\hline Rodrigues et al. (2011) & Human & $\begin{array}{l}\text { Cell } \\
\text { lines }\end{array}$ & Fluoxetine, $24 \mathrm{~h}$ & $\begin{array}{l}\downarrow \mathrm{miR} 124 \mathrm{a} \text { in SH-SY5Y and BE(2)-M17 cell lines } \\
\uparrow \mathrm{miR}-27 \mathrm{~b} \text { in BE(2)-M17 cell line }\end{array}$ \\
\hline \multirow[t]{2}{*}{ Tsankova et al. (2006) } & \multirow[t]{2}{*}{ Mouse } & \multirow[t]{2}{*}{$\mathrm{HC}$} & Imipramine & Pre-treatment: $\uparrow$ methylation of $\mathrm{H} 3 \mathrm{~K} 27$ at $B d n f$ promoters, $\downarrow B d n f$ mRNA after social defeat stress \\
\hline & & & 4 weeks & Post-treatment: $\uparrow \mathrm{H} 3$ acetylation at Bdnf promoters, $\uparrow B d n f$ mRNA, $\downarrow$ HDAC5 mRNA \\
\hline \multirow[t]{4}{*}{ Tsankova et al. (2004) } & \multirow[t]{4}{*}{ SD rat } & \multirow[t]{4}{*}{$\mathrm{HC}$} & ECS & $\uparrow \mathrm{H} 3$ and $\mathrm{H} 4$ acetylation at $B d n f$ promoter II $2 \mathrm{~h}$ after 1 and 7 days $\mathrm{ECS}, \uparrow B d n f$ mRNA \\
\hline & & & 1 or 7 days & $\uparrow \mathrm{H} 3$ acetylation at Bdnf promoters III and IV $24 \mathrm{~h}$ after 7 days ECS, $\uparrow B d n f$ mRNA \\
\hline & & & & $\uparrow \mathrm{H} 3$ and $\mathrm{H} 4$ acetylation at $C$-fos promoter $2 \mathrm{~h}$ after 1 and 7 days ECS, $\uparrow$-fos mRNA \\
\hline & & & & $\begin{array}{l}\downarrow \mathrm{H} 3 \text { acetylation at } \mathrm{Creb} \text { promoter } 2 \mathrm{~h} \text { after } 1 \text { and } 7 \text { days ECS, } \downarrow \text { H4 acetylation } 24 \mathrm{~h} \text { after } 7 \text { days ECS with } \\
\downarrow \text { Creb mRNA }\end{array}$ \\
\hline Zhou et al. (2009) & Wistar & $\mathrm{HC}$ & Lithium, VPA, & 37 miRNAs altered by lithium, 31 miRNAs altered by VPA, nine miRNAs regulated by both drugs: $\downarrow$ let- \\
\hline & & & & \\
\hline
\end{tabular}

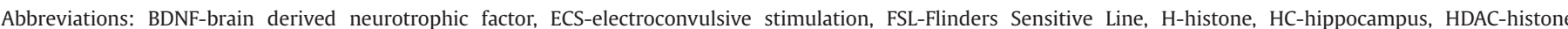

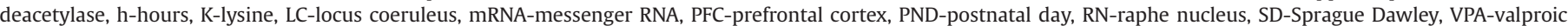
acid.

Table 4

Antidepressant treatment associated effects on miRNA expression in in vitro, preclinical and clinical studies.

\begin{tabular}{|c|c|c|c|c|}
\hline Reference & Species & Tissue & Treatment & Treatment associated epigenetic modification, molecular changes and other outcomes \\
\hline Angelucci et al. (2011) & Human & $\begin{array}{l}\text { Cell } \\
\text { line }\end{array}$ & Paroxetine & $\begin{array}{l}\text { Rapid } \uparrow \text { in } B D N F \text { mRNA expression and protein synthesis followed by } \uparrow \text { in miR-30a-5p, a BDNF } \\
\text { inhibitor, at six and } 12 \text { hours after treatment }\end{array}$ \\
\hline \multirow{3}{*}{$\begin{array}{l}\text { Baudry et al. (2010), } \\
\text { Launay et al. (2011) }\end{array}$} & \multirow[t]{3}{*}{ Mouse } & RN & Fluoxetine applied at & $\downarrow \mathrm{miR}-16$ and serotonin transporter in RN \\
\hline & & LC & RN for 3 days & $\downarrow$ miR-16 and $\uparrow$ serotonin transporter in LC and $\mathrm{HC}$ \\
\hline & & $\mathrm{HC}$ & & Anti-miR-16 applied at $\mathrm{HC}$ results in anti-depressant behaviour \\
\hline \multirow[t]{2}{*}{ Belzeaux et al. (2012) } & \multirow[t]{2}{*}{$\begin{array}{l}\text { Human, } \\
\text { MDD }\end{array}$} & \multirow[t]{2}{*}{ Blood } & $\begin{array}{l}\text { Various } \\
\text { antidepressants }\end{array}$ & $\uparrow \operatorname{miR}-20 b-3 p$, miR-433, miR-409-3p, miR-410, miR-485-3p, miR-133a, miR-145 \\
\hline & & & 8 weeks & $\downarrow \mathrm{miR}-331-5 \mathrm{p}$ \\
\hline $\begin{array}{l}\text { Bocchio-Chiavetto et al. } \\
\text { (2013) }\end{array}$ & $\begin{array}{l}\text { Human, } \\
\text { MDD }\end{array}$ & Blood & $\begin{array}{l}\text { Escitalopram, } 12 \\
\text { weeks }\end{array}$ & $\begin{array}{l}\uparrow 28 \text { miRNAs including BDNF-related miR-132 } \\
\downarrow \text { miR-34c-5p and miR-770-5p }\end{array}$ \\
\hline Oved et al. (2012) & Human & $\begin{array}{l}\text { Cell } \\
\text { line }\end{array}$ & Paroxetine, 3 days & $\begin{array}{l}\text { Paroxetine sensitive cells had higher basal expression levels of miR-151-3p, associated with } \downarrow \text { mRNA } \\
\text { for miR-151-3p effector, CHL1, a neural cell adhesion molecule } \\
\text { Basal levels of miR-212, mir-132, miR-30b*, let-7b and let-7c also differed significantly by more than } \\
1.5 \text { fold between the high and low sensitivity cell groups }\end{array}$ \\
\hline Rodrigues et al. (2011) & Human & $\begin{array}{l}\text { Cell } \\
\text { lines }\end{array}$ & Fluoxetine, $24 \mathrm{~h}$ & $\begin{array}{l}\downarrow \mathrm{miR} 124 \mathrm{a} \text { in SH-SY5Y and BE(2)-M17 cell lines } \\
\uparrow \mathrm{miR}-27 \mathrm{~b} \text { in } \mathrm{BE}(2)-\mathrm{M} 17 \text { cell line }\end{array}$ \\
\hline Zhou et al. (2009) & $\begin{array}{l}\text { Wistar } \\
\text { rat }\end{array}$ & $\mathrm{HC}$ & $\begin{array}{l}\text { Lithium, VPA, } \\
4 \text { weeks }\end{array}$ & $\begin{array}{l}37 \text { miRNAs altered by lithium, } 31 \text { miRNAs altered by VPA, nine miRNAs regulated by both drugs: } \downarrow \text { let- } \\
\text { 7b and let-7c, miR-105, miR-128a, miR-24, miR-30c, miR-34a, miR-221 and miR-136, and } \uparrow \text { miR-144 }\end{array}$ \\
\hline
\end{tabular}

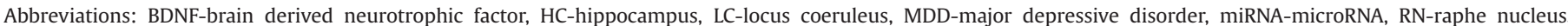
VPA-valproic acid. 
in the mechanism of action of this powerful antidepressant treatment. However, the epigenetic effects of ECS in animal models of depression and ECT in humans are still to be reported.

Epigenetic modification of gene expression has been reported following administration of antidepressant drugs in various models of depression (Table 3). In adult mice, epigenetic modifications of $B d n f$ have been reported after social defeat stress, which results in phenotypic behaviours that mimic depressive symptoms in humans (Tsankova et al., 2006). In a study by Tsankova et al. (2006), social defeat stress was associated with decreased Bdnf mRNA in the hippocampus of mice and was accompanied by an increase in gene-suppressing methylation of histone 3 at lysine 27 at $B d n f$ gene promoter regions. Antidepressant treatment with imipramine in this model resulted in increased mRNA levels for Bdnf. Although methylation of histone 3 at lysine 27 was not reversed by imipramine, compensatory $B d n f$ gene expression enhancing epigenetic modifications were observed, including hyperacetylation of histone 3 at $B d n f$-promoters, and a decrease in mRNA levels for histone deacetylase 5 (HDAC5), an enzyme that decreases gene expression by decreasing histone acetylation (Tsankova et al., 2006). In addition, HDAC5 overexpression prevented the ability of imipramine to reverse the depressive phenotype in stressed animals, highlighting the importance of histone acetylation in the antidepressant effect.

Studies examining the expression of miR-16, which targets the serotonin transporter, have provided insight into the mechanism of action of fluoxetine in the mouse brain (Baudry et al., 2010; Launay et al., 2011). Infusion of fluoxetine into the raphe nucleus, a major source of ascending serotonergic projections in the brain, resulted in a decrease in miR-16 and a two-fold reduction in binding of serotonin transporter (Baudry et al., 2010). Fluoxetine applied at the raphe, also appears to affect miRNA expression in the locus coeruleus (Baudry et al., 2010) and hippocampus (Launay et al., 2011) causing a reduction in miR-16 and a subsequent increase in serotonin transporter levels in both brain regions. Furthermore, neutralisation of miR-16 in the hippocampus by application of anti-miR16 results in antidepressant-like behavioural effects highlighting the importance of its role in the downstream effects of fluoxetine (Launay et al., 2011).

Few studies to date have reported on the epigenetic effects of antidepressant treatment in humans (Belzeaux et al., 2012; Bocchio-Chiavetto et al., 2013; Chen et al., 2011; Lopez et al., 2013; Sharma et al., 2006) (Table 4). Chen et al. (2011) reported an increase in $B D N F$ expression in the prefrontal cortex postmortem that was associated with a decrease in gene-repressing methylation of histone 3 at lysine 27 in patients taking a variety of antidepressants (Chen et al., 2011). In a follow-up study, citalopram treatment for eight weeks induced an increase in BDNF protein levels in peripheral blood of treatment-naïve MDD patients (Lopez et al., 2013). This was accompanied by a decrease in methylation of histone 3 at lysine 27 primarily in blood plasma in patients that were drug responders. miRNA changes following antidepressant treatment have been reported in two studies (Belzeaux et al., 2012; Bocchio-Chiavetto et al., 2013). miRNA changes were examined in blood from 10 patients with MDD following 12 weeks of administration of the SSRI escitalopram. After treatment, 28 miRNAs were upregulated, including the BDNF-related miR-132, while two miRNAs, miR-34c-5p and miR770-5p, were robustly downregulated (Bocchio-Chiavetto et al., 2013). Predicted target genes included growth factors such as $B D N F$ and vascular endothelial growth factor, calcium channels and neurotransmitter receptors. Further analysis indicated that miRNA expression was enriched for pathways important in brain function such as axonal guidance and long-term potentiation.

Collectively, the results of studies in humans and animal models suggest that antidepressant treatment reverses or elicits compensatory epigenetic changes such as histone hyperacetylation and DNA hypomethylation that promote previously decreased gene expression. The research highlighted above also provides evidence of miRNA regulation following antidepressant treatment both in vitro and in vivo. The miRNAs altered by antidepressants are important in neuronal processes that are affected in MDD such as neurogenesis and long-term potentiation which is important in memory formation. Epigenetics-based treatments have shown promising results in clinical trials for cancer (O'Rourke et al., 2013; Qiu et al., 2013; Tan et al., 2010), hepatitis C (Janssen et al., 2013) and provide an exciting new field for the development of therapies for MDD. Gaining a greater understanding of the epigenetic mechanisms underlying antidepressant mechanisms may guide the development of novel treatments for MDD, e.g. targeted HDAC and DNA methyltransferase inhibitors, and inhibition of miRNAs with small molecules. Additionally, miRNA expression profiles may serve as useful biomarkers to predict treatment response in individuals.

\section{Limitations}

Given the novelty of the field, a narrative approach was taken with regard to this review which has its limitations in terms of subjective bias. This review is meant to give an overview of an emerging field and does not lend itself to meta-analysis. Many of the included studies were carried out in small samples and have not been validated or replicated. Caution should also be used in extrapolating findings from pre-clinical settings to patient populations. The technical analyses of epigenetic alterations are still under development and in some instances there has been failure to replicate findings in the field of neuropsychiatric epigenetics (Houston et al., 2013). For example, inconsistent results have been reported regarding hypermethylation of the REELIN gene promoter in brains of patients with schizophrenia (Abdolmaleky et al., 2005; Tochigi et al., 2008). The current methods available to study epigenetic factors can be crude and imprecise, and researchers face a number of challenges when studying epigenetic changes, particularly in humans, some of which are detailed below.

Disease aetiology and varying exposure to environmental factors, including alcohol and psychostimulants, can alter epigenetic marks such as DNA methylation. Variations in glia to neuron ratio can introduce a high degree of heterogeneity and thus affect reproducibility of epigenetic studies examining cohort-based effects in relatively small samples (Houston et al., 2013).

In addition, the techniques for analysis of chromatin activation or DNA methylation status typically require relatively large amounts of input material and lack single-cell resolution (Akbarian and Huang, 2009). This can pose a problem when working with brain tissue, particularly in preclinical studies due to the relatively small brain size of rodents. One solution is to use whole-brain lysates. However, epigenetic changes can vary between brain areas (Roth et al., 2009) and researchers run the risk of neglecting subtle, region-specific changes. Although regionspecific studies give a more precise view of epigenetic changes in the brain, tissue-homogenates comprise a heterogeneous set of neurons, glia and other cells, making identification of specific neuronal subtype (e.g. GABAergic interneuron) epigenetic alterations difficult (Houston et al., 2013). Purification techniques for separating neuronal and non-neuronal cells are now available and may improve the precision of post-mortem brain analyses.

Alternatively to post-mortem brain tissue, peripheral blood offers a relatively accessible biological fluid that can be sampled multiple times from the same individual. Using peripheral blood, changes in miRNA expression and epigenetic modulation of genes such as BDNF have been reported in patients with MDD before and 
after antidepressant treatment (Tables 2 and 4; (Lopez et al., 2013)). It remains to be seen to what degree changes in blood represent changes in the brain (Peedicayil, 2008). Furthermore, it is not clear if changes in blood reflect the pathological state or compensatory alterations in response to the pathological condition and/or treatment (Fass et al., 2013). Nonetheless, alterations in peripheral blood may serve as useful biomarkers in the diagnosis and treatment of psychiatric conditions including MDD (Cheng et al., 2013; Lopez et al., 2013).

Alterations in chromatin remodelling and/or DNA methylation can be measured globally or at a specific gene promoter. Promoter specific studies usually involve an isolation step to separate the epigenetically modified DNA (e.g. chromatin immunoprecipitation or bisulfite conversion), followed by analysis using PCR amplification (Fuchikami et al., 2011; Roth et al., 2009; Tsankova et al., 2004). Researchers examining changes in this manner must take into account multiple splice variants of genes of interest and design primers and PCR assays accordingly. For example, transcription of BDNF can arise from 11 different exons in humans and eight in rats, giving rise to multiple transcripts, known as splice variants, which can be individually epigenetically regulated (Boulle et al., 2012; Tsankova et al., 2004). As mentioned above, heterogeneity at the subject and tissue levels can also affect reproducibility in target-gene focused investigations. Furthermore, recent research indicates that in some conditions (e.g. autism), chromatin remodelling affects gene expression in subjects on an individual basis, a caveat which may limit findings in certain genespecific studies (Houston et al., 2013).

Methodologies to assess epigenetic alterations on a global, genome-wide basis may help to overcome some of the limitations of target specific studies and provide the opportunity to identify previously unknown mechanisms involved in the pathology and treatment of MDD (Vialou et al., 2013). In terms of chromatin remodelling for example, genome-wide analysis was initially carried out using a technique known as ChIP-chip. Chromatin immunoprecipitation (ChIP) is a procedure whereby DNA bound to epigenetically modified lysine residues on histone tails (e.g. histone 3 at lysine 9, see Fig. 2) can be precipitated using targeted antibodies. Sequences of interest are then identified by hybridising bound DNA to a chip (microarray) containing a number of known DNA sequences. Wilkinson et al. (2009) used ChIP-chip with an antibody for histone 3 lysine 9 to identify genes that were upregulated or downregulated in the nucleus accumbens in mice one month after exposure to chronic stress, before and after imipramine treatment.

ChIP-chip is now being superseded by ChIP-seq (Houston et al., 2013). ChIP-seq analysis, which combines ChIP with next generation sequencing (NGS) technologies involving high-throughput sequencing of all enriched DNA sequences, provides the opportunity for increased sensitivity, higher resolution and more comprehensive screening of genomic profiles whilst requiring less input material than ChIP-chip (Park, 2009). NGS analysis is now also being combined with other techniques to identify epigenetic marks on a genomic scale. For instance, methods for characterising DNA methylation in human and rodent brain tissue have been combined with NGS analysis to create a database of genome-wide DNA methylation profiles (Xin et al., 2012). NGS also has the potential to examine miRNA alterations in psychiatric conditions and has already been used to study miRNA changes in the hippocampus of Alzheimer's patients (Lau et al., 2013). With the recent development of more widely available and affordable sequencing platforms, as well as databases containing epigenetic profiles of the human and rodent brain allowing cross-study and -species comparisons, NGS will enhance precision and resolution in pre-clinical and clinical epigenetic studies (Fass et al., 2013; Wang et al., 2013; Xin et al., 2012).

\section{Summary and conclusions}

Epigenetic mechanisms operate alongside the DNA sequence and promote or suppress gene expression, ultimately influencing protein production. Epigenetic modifications of gene expression include alterations in DNA methylation, chromatin remodelling and miRNA expression patterns. Epigenetics is an important new area in the field of MDD research and provides a mechanism for understanding the link between the long-term effects of adverse life events and the changes in gene expression that are associated with depression. Indeed, risk factors for depression, such as early life stress, are associated with epigenetic changes in gene expression in both preclinical and clinical studies. Persistent epigenetic modification of gene expression induced by environmental stimuli may also play a role in the transgenerational transmission of behavioural disturbances such as depression. In individuals with MDD, epigenetic modification of genes such as BDNF and its receptor Trk $B$ as well as synapsins and GABA receptor subunits have been observed. Alterations in miRNA levels and polymorphisms in miRNAs, their precursors, their target mRNAs and in genes that regulate miRNA biogenesis have also been noted in MDD. Although still a developing field, in the future, epigenetic modifications of gene expression may provide novel biomarkers to predict future susceptibility and/or onset of MDD, to improve diagnosis and to better understand the pathophysiology of depression.

Epigenetics also appears to be important in the mode of action of antidepressant treatments. In preclinical studies, ECS, the animal model equivalent of the most acutely effective treatment for depression, causes alterations in chromatin activation status and DNA methylation of depression-related genes. Antidepressant drug treatments appear to reverse or bring about compensatory changes in gene expression in an animal model of depression and in clinical studies of MDD. Furthering our knowledge of the epigenetic modifications of gene expression elicited after antidepressant treatment may aid in the development of epigeneticsbased therapies for depression and to predict treatment outcome.

\section{Conflict of interest}

All authors declare that they have no conflicts of interest.

\section{Role of funding source}

Not applicable.

\section{Acknowledgements}

This work was supported by awards from the Health Research Board (TRA/2007/5) and the Friends of St. Patrick's Hospital.

\section{References}

Abdolmaleky, H.M., et al., 2005. Hypermethylation of the reelin (RELN) promoter in the brain of schizophrenic patients: a preliminary report. Am. J. Med. Genet. B Neuropsych. Genet. 134B, 60-66.

Akbarian, S., Huang, H.S., 2009. Epigenetic regulation in human brain-focus on histone lysine methylation. Biol. Psychiatry 65, 198-203.

Angelucci, F., et al., 2011. Paroxetine rapidly modulates the expression of brainderived neurotrophic factor mRNA and protein in a human glioblastomaastrocytoma cell line. Pharmacology 87, 5-10.

Bai, M., et al., 2012. Abnormal hippocampal BDNF and miR-16 expression is associated with depression-like behaviors induced by stress during early life. PLoS One 7, e46921.

Baudry, A., et al., 2010. miR-16 targets the serotonin transporter: a new facet for adaptive responses to antidepressants. Science 329, 1537-1541.

Belzeaux, R., et al., 2012. Responder and nonresponder patients exhibit different peripheral transcriptional signatures during major depressive episode. Transl. Psychiatry 2, e185.

Berger, S.L., 2007. The complex language of chromatin regulation during transcription. Nature 447, 407-412.

Bocchio-Chiavetto, L., et al., 2013. Blood microRNA changes in depressed patients during antidepressant treatment. Eur. Neuropsychopharmacol. 23, 602-611. 
Boulle, F., et al., 2012. Epigenetic regulation of the BDNF gene: implications for psychiatric disorders. Mol. Psychiatry 17, 584-596.

Brand, S.R., et al., 2010. The impact of maternal childhood abuse on maternal and infant HPA axis function in the postpartum period. Psychoneuroendocrinology 35, 686-693.

Bredy, T.W., et al., 2011. MicroRNA regulation of neural plasticity and memory. Neurobiol. Learn. Mem. 96, 89-94.

Bredy, T.W., et al., 2007. Histone modifications around individual BDNF gene promoters in prefrontal cortex are associated with extinction of conditioned fear. Learn. Mem. 14, 268-276.

Carthew, R.W., Sontheimer, E.J., 2009. Origins and mechanisms of miRNAs and siRNAs. Cell 136, 642-655.

Chen, E.S., et al., 2011. The epigenetic effects of antidepressant treatment on human prefrontal cortex BDNF expression. Int. J. Neuropsychopharmacol. 14, 427-429.

Chen, J., et al., 2012. Maternal deprivation in rats is associated with corticotrophinreleasing hormone $(\mathrm{CRH})$ promoter hypomethylation and enhances CRH transcriptional responses to stress in adulthood. J. Neuroendocrinol. 24 1055-1064.

Chendrimada, T.P., et al., 2005. TRBP recruits the Dicer complex to Ago2 for microRNA processing and gene silencing. Nature 436, 740-744.

Cheng, L., et al., 2013. The detection of microRNA associated with Alzheimer's disease in biological fluids using next-generation sequencing technologies. Front. Genet. 4, 150.

Chong, M.M., et al., 2010. Canonical and alternate functions of the microRNA biogenesis machinery. Genes Dev. 24, 1951-1960.

Clancy, S., Brown, W., 2008. Translation: DNA to mRNA to protein. Nat. Edu. 1, 1.

Crosio, C., et al., 2003. Chromatin remodeling and neuronal response: multiple signaling pathways induce specific histone $\mathrm{H} 3$ modifications and early gene expression in hippocampal neurons. J. Cell Sci. 116, 4905-4914.

Cruceanu, C., et al., 2013. H3K4 tri-methylation in synapsin genes leads to different expression patterns in bipolar disorder and major depression. Int. J. Neuropsychopharmacol. 16, 289-299.

Devlin, A.M., et al., 2010. Prenatal exposure to maternal depressed mood and the MTHFR C677T variant affect SLC6A4 methylation in infants at birth. PLoS One 5 e12201.

Dillon, S.C., et al., 2005. The SET-domain protein superfamily: protein lysine methyltransferases. Genome Biol. 6, 227.

Dwivedi, Y., et al., 2003. Altered gene expression of brain-derived neurotrophic factor and receptor tyrosine kinase B in postmortem brain of suicide subjects. Arch. Gen. Psychiatry 60, 804-815.

Dyrvig, M., et al., 2012. Epigenetic regulation of Arc and c-Fos in the hippocampus after acute electroconvulsive stimulation in the rat. Brain Res. Bull. 88, 507-513.

Eberharter, A., Becker, P.B., 2002. Histone acetylation: a switch between repressive and permissive chromatin. Second in review series on chromatin dynamics. EMBO Rep. 3, 224-229.

Edvardsen, J., et al., 2009. Unipolar depressive disorders have a common genotype. Affect. Disord. 117, 30-41.

Encode Project Consortium, 2012. An integrated encyclopedia of DNA elements in the human genome. Nature 489, 57-74

Eranti, S., et al., 2007. A randomized, controlled trial with 6-month follow-up of repetitive transcranial magnetic stimulation and electroconvulsive therapy for severe depression. Am. J. Psychiatry 164, 73-81.

Ernst, C., et al., 2009a. Histone methylation and decreased expression of TrkB.T1 in orbital frontal cortex of suicide completers. Mol. Psychiatry 14, 830-832.

Ernst, C., et al., 2009b. Alternative splicing, methylation state, and expression profile of tropomyosin-related kinase $B$ in the frontal cortex of suicide completers. Arch. Gen. Psychiatry 66, 22-32.

Esteller, M., 2011. Non-coding RNAs in human disease. Nat. Rev. Genet. 12, 861-874.

Fass, D.M., et al., 2013. Epigenetic mechanisms in mood disorders: targeting neuroplasticity. Neuroscience, doi:10.1016/j.neuroscience.2013.1001.1041 (in press).

Franklin, T.B., et al., 2010. Epigenetic transmission of the impact of early stress across generations. Biol. Psychiatry 68, 408-415.

Friedman, R.C., et al., 2009. Most mammalian mRNAs are conserved targets of microRNAs. Genome Res. 19, 92-105.

Fuchikami, M., et al., 2009. Single immobilization stress differentially alters the expression profile of transcripts of the brain-derived neurotrophic factor (BDNF) gene and histone acetylation at its promoters in the rat hippocampus. Int. J. Neuropsychopharmacol. 12, 73-82.

Fuchikami, M., et al., 2011. DNA methylation profiles of the brain-derived neurotrophic factor (BDNF) gene as a potent diagnostic biomarker in major depression. PLoS One 6, e23881.

Grunstein, M., 1997. Histone acetylation in chromatin structure and transcription. Nature 389, 349-352.

Haque, F.N., et al., 2009. Not really identical: epigenetic differences in monozygotic twins and implications for twin studies in psychiatry. Am. J. Med. Genet. C Sem. Med. Genet. 151C, 136-141.

Harper, L.V., 2005. Epigenetic inheritance and the intergenerational transfer of experience. Psychol. Bull. 131, 340-360.

Havens, M.A., et al., 2012. Biogenesis of mammalian microRNAs by a non-canonica processing pathway. Nucleic Acids Res. 40, 4626-4640.

Hayes, J.J., Hansen, J.C., 2001. Nucleosomes and the chromatin fiber. Curr. Opin. Genet. Dev. 11, 124-129.

He, Y., Zhou, Y., Xi, Q., Cui, H., Luo, T., Song, H., Nie, X., Wang, L., Ying, B., 2012. Genetic variations in microRNA processing genes are associated with susceptibility in depression. DNA Cell Biol. 31, 1499-1506.
Hebbes, T.R., et al., 1988. A direct link between core histone acetylation and transcriptionally active chromatin. EMBO J. 7, 1395-1402.

Heim, C., Binder, E.B., 2012. Current research trends in early life stress and depression: review of human studies on sensitive periods, gene-environment interactions, and epigenetics. Exp. Neurol. 233, 102-111.

Hervouet, E., et al., 2009. Dnmt3/transcription factor interactions as crucial players in targeted DNA methylation. Epigenetics 4, 487-499.

Houston, I., et al., 2013. Epigenetics in the human brain. Neuropsychopharmacology $38,183-197$.

Iga, J., et al., 2007. Altered HDAC5 and CREB mRNA expressions in the peripheral leukocytes of major depression. Prog. Neuropsychopharmacol. Biol. Psychiatry 31, 628-632.

Im, H.I., Kenny, P.J., 2012. MicroRNAs in neuronal function and dysfunction. Trends Neurosci. 35, 325-334.

Janssen, H.L., et al., 2013. Treatment of HCV infection by targeting microRNA. N. Engl. J. Med. 368, 1685-1694.

Jiao, J., et al., 2013. Gestational environment programs adult depression-like behavior through methylation of the calcitonin gene-related peptide gene, Mol. Psychiatry, (in press) http://dx.doi.org/10.1038/mp.2012.1136.

Kawamata, T., Tomari, Y., 2010. Making RISC. Trends Biochem. Sci. 35, 368-376.

Keller, S., et al., 2011. TrkB gene expression and DNA methylation state in Wernicke area does not associate with suicidal behavior. J. Affect. Disord. 135, 400-404.

Keller, S., et al., 2010. Increased BDNF promoter methylation in the Wernicke area of suicide subjects. Arch. Gen. Psychiatry 67, 258-267.

Kendler, K.S., et al., 2002. Toward a comprehensive developmental model for major depression in women. Am. J. Psychiatry 159, 1133-1145.

Kendler, K.S., et al., 2006. Toward a comprehensive developmental model for major depression in men. Am. J. Psychiatry 163, 115-124.

Khorasanizadeh, S., 2004. The nucleosome: from genomic organization to genomic regulation. Cell 116, 259-272.

Kim, H.K., et al., 2009. Intergenerational transmission of internalising and externalising behaviours across three generations: gender-specific pathways. Crim. Behav. Ment. Health 19, 125-141.

Kim, Y.K., et al., 2007. Low plasma BDNF is associated with suicidal behavior in major depression. Prog. Neuropsychopharmacol. Biol. Psychiatry 31, 78-85.

Kloosterman, W.P., Plasterk, R.H., 2006. The diverse functions of microRNAs in animal development and disease. Dev. Cell 11, 441-450.

Kolshus, E., et al., 2013. When less is more-microRNAs and psychiatric disorders. Acta Psychiatr. Scand., doi:10.1111/acps.12191 (in press).

Korzus, E., et al., 2004. CBP histone acetyltransferase activity is a critical component of memory consolidation. Neuron 42, 961-972.

Kozomara, A., Griffiths-Jones, S., 2011. miRBase: integrating microRNA annotation and deep-sequencing data. Nucleic Acids Res. 39, D152-D157.

Krol, J., et al., 2010. The widespread regulation of microRNA biogenesis, function and decay. Nat. Rev. Genet. 11, 597-610.

Lam, L.L., et al., 2012. Factors underlying variable DNA methylation in a human community cohort. Proc. Nat. Acad. Sci. U.S.A. 109 (Suppl 2), 17253-17260.

Lau, P., et al., 2013. Alteration of the microRNA network during the progression of Alzheimer's disease. EMBO Mol. Med. 5, 1613-1634.

Launay, J.M., et al., 2011. Raphe-mediated signals control the hippocampal response to SRI antidepressants via miR-16. Transl. Psychiatry 1, e56.

Lee, B.H., Kim, Y.K., 2010. The roles of BDNF in the pathophysiology of major depression and in antidepressant treatment. Psychiatry Invest. 7, 231-235.

Levine, A., et al., 2012. Early life stress triggers sustained changes in histone deacetylase expression and histone $\mathrm{H} 4$ modifications that alter responsiveness to adolescent antidepressant treatment. Neurobiol. Dis. 45, 488-498.

Lopez, J.P., et al., 2013. Epigenetic regulation of BDNF expression according to antidepressant response. Mol. Psychiatry 18, 398-399.

Luikart, B.W., et al., 2012. Dentate gyrus neurogenesis, integration and microRNAs. Behav. Brain Res. 227, 348-355.

Magill, S.T., et al., 2010. microRNA-132 regulates dendritic growth and arborization of newborn neurons in the adult hippocampus. Proc. Nat. Acad. Sci. U.S.A. 107, 20382-20387.

Markham, J.A., Koenig, J.I., 2011. Prenatal stress: role in psychotic and depressive diseases. Psychopharmacology (Berlin) 214, 89-106.

Matrisciano, F., et al., 2013. Epigenetic modifications of GABAergic interneurons are associated with the schizophrenia-like phenotype induced by prenatal stress in mice. Neuropharmacology 68, 184-194.

McGowan, P.O., et al., 2009. Epigenetic regulation of the glucocorticoid receptor in human brain associates with childhood abuse. Nat. Neurosci. 12, 342-348.

McGowan, P.O., et al., 2008. Promoter-wide hypermethylation of the ribosomal RNA gene promoter in the suicide brain. PLoS One 3, e2085.

Melas, P.A., et al., 2012. Antidepressant treatment is associated with epigenetic alterations in the promoter of P11 in a genetic model of depression. Int. J. Neuropsychopharmacol. 15, 669-679.

Middeldorp, C.M., et al., 2005. Familial clustering of major depression and anxiety disorders in Australian and Dutch twins and siblings. Twin Res. Hum. Genet. 8, 609-615.

Mizuno, K., et al., 2012. Long-lasting regulation of hippocampal Bdnf gene transcription after contextual fear conditioning. Genes Brain Behav. 11, 651-659.

Morgan, C.P., Bale, T.L., 2011. Early prenatal stress epigenetically programs dysmasculinization in second-generation offspring via the paternal lineage. J. Neurosci. 31, 11748-11755.

Morgunkova, A., Barlev, N.A., 2006. Lysine methylation goes global. Cell Cycle 5, 1308-1312. 
Mueller, B.R., Bale, T.L., 2008. Sex-specific programming of offspring emotionality after stress early in pregnancy. J. Neurosci. 28, 9055-9065.

Mulligan, C.J., et al., 2012. Methylation changes at NR3C1 in newborns associate with maternal prenatal stress exposure and newborn birth weight. Epigenetics 7, 853-857.

Murgatroyd, C., et al., 2009. Dynamic DNA methylation programs persistent adverse effects of early-life stress. Nat. Neurosci. 12, 1559-1566.

Mychasiuk, R., et al., 2011. Intensity matters: brain, behaviour and the epigenome of prenatally stressed rats. Neuroscience 180, 105-110.

Novikova, S.I., et al., 2003. Maternal cocaine administration in mice alters DNA methylation and gene expression in hippocampal neurons of neonatal and prepubertal offspring. PLoS One 3, e1919.

O'Rourke, C.J., et al., 2013. Manipulating the epigenome for the treatment of urological malignancies. Pharmacol. Ther. 138, 185-196.

Oberlander, T.F., et al., 2008. Prenatal exposure to maternal depression, neonatal methylation of human glucocorticoid receptor gene (NR3C1) and infant cortisol stress responses. Epigenetics 3, 97-106.

Olsen, L., et al., 2009. MicroRNAs show mutually exclusive expression patterns in the brain of adult male rats. PLoS One 4, e7225.

Onishchenko, N., et al., 2008. Long-lasting depression-like behavior and epigenetic changes of BDNF gene expression induced by perinatal exposure to methylmercury. J. Neurochem. 106, 1378-1387.

Oved, K., et al., 2012. Genome-wide miRNA expression profiling of human lymphoblastoid cell lines identifies tentative SSRI antidepressant response biomarkers. Pharmacogenomics 13, 1129-1139.

Park, P.J., 2009. ChIP-seq: advantages and challenges of a maturing technology. Nat. Rev. Genet. 10, 669-680.

Pasquinelli, A.E., 2012. MicroRNAs and their targets: recognition, regulation and an emerging reciprocal relationship. Nat. Rev. Genet. 13, 271-282.

Peedicayil, J., 2008. Epigenetic biomarkers in psychiatric disorders. Br. J. Pharmacol. $155,795-796$

Philibert, R.A., et al., 2008. The relationship of 5HTT (SLC6A4) methylation and genotype on mRNA expression and liability to major depression and alcohol dependence in subjects from the Iowa Adoption Studies. Am. J. Med. Genet. B. Neuropsychiatry Genet. 147B, 543-549.

Pile, L.A., et al., 2003. The SIN3 deacetylase complex represses genes encoding mitochondrial proteins: implications for the regulation of energy metabolism. J. Biol. Chem. 278, 37840-37848.

Poulter, M.O., et al., 2008. GABAA receptor promoter hypermethylation in suicide brain: implications for the involvement of epigenetic processes. Biol. Psychiatry 64, 645-652.

Qiu, T., et al., 2013. Effects of treatment with histone deacetylase inhibitors in solid tumors: a review based on 30 clinical trials. Futures Oncol. 9, 255-269.

Radtke, K.M., et al., 2011. Transgenerational impact of intimate partner violence on methylation in the promoter of the glucocorticoid receptor. Transl. Psychiatry 1 , e21.

Rahman, O.A., et al., 2010. Analysis of a polymorphic microRNA target site in the purinergic receptor P2RX7 gene. Electrophoresis 31, 1790-1795.

Rodrigues, A.C., et al., 2011. MicroRNA expression is differentially altered by xenobiotic drugs in different human cell lines. Biopharm. Drug Dispos. 32, 355-367.

Roth, T.L., et al., 2009. Lasting epigenetic influence of early-life adversity on the BDNF gene. Biol. Psychiatry 65, 760-769.

Roth, T.L., et al., 2011. Epigenetic modification of hippocampal Bdnf DNA in adult rats in an animal model of post-traumatic stress disorder. J. Psychiatr. Res. 45, 919-926.

Saba, R., Schratt, G.M., 2010. MicroRNAs in neuronal development, function and dysfunction. Brain Res. 1338, 3-13.

Saus, E., et al., 2010. Genetic variants and abnormal processing of pre-miR-182, a circadian clock modulator, in major depression patients with late insomnia. Hum. Mol. Genet. 19, 4017-4025.

Schroeder, M., et al., 2012. The epigenetic code in depression: implications for treatment. Clin. Pharmacol. Ther. 91, 310-314.

Sempere, L.F., et al., 2004. Expression profiling of mammalian microRNAs uncovers a subset of brain-expressed microRNAs with possible roles in murine and human neuronal differentiation. Genome Biol. 5, R13.
Sharma, R.P., et al., 2006. Valproic acid and chromatin remodeling in schizophrenia and bipolar disorder: preliminary results from a clinical population. Schizophr. Res. 88, 227-231.

Smalheiser, N.R., et al., 2012. MicroRNA expression is down-regulated and reorganized in prefrontal cortex of depressed suicide subjects. PLoS One 7, e33201.

Sterrenburg, L, et al., 2011. Chronic stress induces sex-specific alterations in methylation and expression of corticotropin-releasing factor gene in the rat. PLoS One 6, e28128.

Szyf, M., 2006. Targeting DNA methylation in cancer. Bull. Cancer 93, 961-972.

Tachibana, M., et al., 2008. G9a/GLP complexes independently mediate H3K9 and DNA methylation to silence transcription. EMBO J. 27, 2681-2690.

Talge, N.M., et al., 2007. Antenatal maternal stress and long-term effects on child neurodevelopment: how and why? J. Child Psychol. Psychiatry 48, 245-261.

Tan, J., et al., 2010. Novel histone deacetylase inhibitors in clinical trials as anticancer agents. J. Hematol. Oncol. 3, 5 .

Thompson Ray, M., et al., 2011. Decreased BDNF, trkB-TK+ and GAD67 mRNA expression in the hippocampus of individuals with schizophrenia and mood disorders. J. Psychiatry Neurosci. 36, 195-203.

Tochigi, M., et al., 2008. Methylation status of the reelin promoter region in the brain of schizophrenic patients. Biol. Psychiatry 63, 530-533.

Toledo-Rodriguez, M., et al., 2010. Maternal smoking during pregnancy is associated with epigenetic modifications of the brain-derived neurotrophic factor- 6 exon in adolescent offspring. Am. J. Med. Genet. B Neuropsychiatr. Genet. 153B, $1350-1354$.

Tsankova, N.M., et al., 2006. Sustained hippocampal chromatin regulation in a mouse model of depression and antidepressant action. Nat. Neurosci. 9 $519-525$.

Tsankova, N.M., et al., 2004. Histone modifications at gene promoter regions in rat hippocampus after acute and chronic electroconvulsive seizures. J. Neurosci. 24 5603-5610.

Uchida, S., et al., 2010. Early life stress enhances behavioral vulnerability to stress through the activation of REST4-mediated gene transcription in the media prefrontal cortex of rodents. J. Neurosci. 30, 15007-15018.

Uchida, S., et al., 2011. Epigenetic status of Gdnf in the ventral striatum determines susceptibility and adaptation to daily stressful events. Neuron 69, 359-372.

Uddin, M., et al., 2011. Epigenetic and inflammatory marker profiles associated with depression in a community-based epidemiologic sample. Psychol. Med. 41, 997-1007.

UK Ect Review Group, 2003. Efficacy and safety of electroconvulsive therapy in depressive disorders: a systematic review and meta-analysis. Lancet 361 799-808.

Vialou, V., et al., 2013. Epigenetic mechanisms of depression and antidepressant action. Annu. Rev. Pharmacol. Toxicol. 53, 59-87.

Wang, Z., et al., 2013. The role and challenges of exome sequencing in studies of human diseases. Front. Genet. 4, 160.

Weaver, I.C., et al., 2004. Epigenetic programming by maternal behavior. Nat. Neurosci. 7, 847-854.

Weber, M., Schubeler, D., 2007. Genomic patterns of DNA methylation: targets and function of an epigenetic mark. Curr. Opin. Cell Biol. 19, 273-280.

Wilkinson, M.B., et al., 2009. Imipramine treatment and resiliency exhibit similar chromatin regulation in the mouse nucleus accumbens in depression models. J. Neurosci. 29, 7820-7832.

Wray, N.R., et al., 2012. Genome-wide association study of major depressive disorder: new results, meta-analysis, and lessons learned. Mol. Psychiatry 17 $36-48$.

Wu, L., et al., 2006. MicroRNAs direct rapid deadenylation of mRNA. Proc. Nat. Acad Sci. U.S.A. 103, 4034-4039.

Xin, Y., et al., 2012. MethylomeDB: a database of DNA methylation profiles of the brain. Nucleic Acids Res, 40, D1245-D1249.

Xu, Y., et al., 2010. A polymorphism in the microRNA-30e precursor associated with major depressive disorder risk and P300 waveform. J. Affect. Disord. 127, 332-336.

Yi, R., et al., 2003. Exportin-5 mediates the nuclear export of pre-microRNAs and short hairpin RNAs. Genes Dev. 17, 3011-3016.

Zhou, R., et al., 2009. Evidence for selective microRNAs and their effectors as common long-term targets for the actions of mood stabilizers. Neuropsychopharmacology 34, 1395-1405. 